\title{
VODNÍ MLÝN JAKO OBJEKT ARCHEOLOGICKÉHO VÝZKUMU
}

\author{
LUCIE GALUSOVÁ
}

\begin{abstract}
Abstrakt: Př́spěvek shrnuje doposud provedené archeologické odkryvy objektů interpretovaných jako středověké vodní mlýny v Čechách, na Moravě, v Německu, Rakousku a Polsku a jako výsledek dosavadního bádáni autorky prezentuje hypotetický model středověkého venkovského vodního mlýna v českých zemích, který zahrnuje zakládáni a vnějši podobu mlýnské stavby, stejně jako složeni a funkce středověkého mlecího mechanismu.
\end{abstract}

Kličová slova: středověk - archeologický odkryv-vodní mlýn-mlýnská technologie.

\section{Watermills as Subjects of Archaeological Research}

Abstract: This contribution sums up archaeological excavations of features interpreted as medieval watermills in Bohemia, Moravia, Germany, Austria and Poland. The outcome will be a hypothetical model of a rural medieval watermill in the Czech lands including the establishment and external form of the structure, as well as the internal equipment of the medieval milling mechanism.

Key words: Middle Ages - archaeological excavations - watermill - milling technology.

\section{1 Úvod}

Výzkum vodních mlýnů v Čechách a na Moravě se v minulosti pojil především s odkryvem či průzkumem zaniklých středověkých vesnic (Klápště 1978, 423-475; Nekuda 2006, 128-141). Několik objektů bylo odkryto v souvislosti se záchrannými archeologickými pracemi (Kudrnáč 1972, 428-432; 1983, 7-26; Kašpar-Smejtek-Vařeka 1999, 101-109; Beková-Dragoun 2004, 25; Košt’ál 2012, 2) a do popředí se dostal též archeologický nedestruktivní výzkum, který odhalil několik předpokládaných mlýnských děl (Zrůstová 2007, 48-5 3, 74; Fröhlich-Kovář-Pešta 2011, 249-262). Mimo vlastní zaniklé stavby mlýnů lze uvést též nálezy mlecích kamenů či jejich zlomků (např. Kudrnáč 1972, 428-432; 1983, 646-655; Hejhal-Hrubý-Malý 2006, 259-288; Hoch 2008; Fröhlich-Kovář-Pešta 2011, 249-262), které však byly systematičtěji zkoumány jen výjimečně (Hoch 2008). V př́ípadě práce A. Hocha však šlo pouze o kameny z rudných mlýnů. Z uvedeného vyplývá, že systematický archeologický výzkum vodních mlýnů nebyl doposud realizován. Na vině snad může být minimum získaných informací z většiny doposud provedených archeologických výzkumů v Čechách a na Moravě. Nové impulzy tomuto bádání dodaly až množící se záchranné archeologické výzkumy vodních mlýnů v zahraničí. Přesto je však pramenná základna stále relativně nízká a poznání omezené. Tento problém lze částečně kompenzovat studiem etnografických (např. Jüttemann 1990; Suppan 1995; Štěpán-Křivanová 2000) a ikonografických pramenů, ${ }^{1}$ obé má však svá úskalí. Etnografie se zabývá až raně novověkými mlýnskými díly a u ikonografických pramenů je třeba obezřetně sledovat autentičnost daného vyobrazení. Tuto hodnověrnost jmenovaných pramenů je však archeolog schopen posoudit jen v omezené míře, a proto tento text s ikonografií pracuje minimálně.

\section{Stř̌edověký vodní mlýn}

V české oblasti již od středověku převládl vodní mlýn oproti mlýnu větrnému (Žemlička $2013,30)$, přičemž podstatnou roli v této souvislosti hrál vodní obilný mlýn, vnímaný jako velmi

\footnotetext{
1 Kupř́kladu velmi významné je první známé technické vyobrazení výstroje vodního mlýna uvedeného v díle Hortus deliciarum od Herrady von Landsberg (Mager-Meißner-Orf 1988, 16/6). Tento spis, bohatě ilustrovaný, sloužil ke vzdělávání jeptišek (vznik kolem roku 1160/70). Jako relevantní ikonografický pramen lze dále uvést dílo Conrada Kyesera, pojednávající o válečném umění, kde je mimo jiné zobrazen i bedněný vodní mlýn s kolem na horní vodu nalézající se pod obléhaným hradem (Pfau 1967, fol. 84r). Z českého prostředí lze uvést dílo zvané Krumlovský kodex Liber depictus, který zobrazuje českokrumlovský klášterní mlýn na spodní vodu z první poloviny 14. století (Schmidt-Unterkircher 1967, fol. 128v). Významným ikonografickým pramenem k vodním mlýnům jsou též německé anonymy uložené ve státní knihovně v Mnichově (Bayerische Staatsbibliothek München), jež jsou kupřikladu publikovány v knize Die Kulturgeschichte der Mühlen (Mager-Meißner-Orf 1988, 34, obr. 23 a 53 , obr. 39 )
} 
důležitý ekonomický, technický i krajinný prvek (Mlynka 2006, 411), chápaný jako mechanické zařízení na vodní pohon, které zpracovává obilné zrno na mlýnské produkty (mouka, šrot, kroupy; Hanušin 1970, 195). Jmenovaný typ zařízení se tak stal též hlavním předmětem této práce. Termín vodní obilný mlýn, jenž má kořeny čistě heuristické, nikoli kulturně-historické, je možné dále členit na moučný, př́ípadně šrotový (tamtéž, 195-199). Obilí se zpracovávalo na speciálně vybraných a upravených kamenech, které se nazývají mlecí kameny. Současně je třeba poznamenat, že vzhledem k terminologické nejistotě, interpretačním problémům a úzkým vztahům mezi jednotlivými zařízeními na vodní pohon byla $\mathrm{v}$ této práci věnována pozornost nejen vodnímu mlýnu (viz zlatorudný mlýn na řece Otavě).

Výzkum vodního mlýna byl v této práci omezen pouze na vesnické prostředí, jelikož agrární venkov jako relativně dobře archeologicky poznané prostředí nabízí určité paralely k jeho stavební podobě. Archeologické odkryvy mlýnských děl ve středoevropském kontextu dále naznačily primární existenci vodního mlýna s vertikálním kolem (srov. Kind 2007, 379-382). Z tohoto důvodu se text věnuje výhradně tomuto typu vodního mlýna.

\section{Cíle a metoda}

V této práci jsem se pokusila shrnout provedené archeologické odkryvy středověkých vodních mlýnů v českých zemích i v přilehlém zahraničí a na tomto základě stanovit předpokládaný vzhled a výstroj středověkého venkovského vodního mlýna.

Okruh otázek byl řešen pomocí studia dostupné literatury a současně též vlastním archeologickým výzkumem provedeným standardními metodami a dokumentačními technikami. Pro přehlednost zjištěných situací a relevantních fragmentů artefaktů nalezených v rámci jednotlivých záchranných archeologických výzkumů realizovaných v Čechách, na Moravě, v Německu, Rakousku a Polsku (obr. 1) byla sestavena základní databáze (tab. 1). Na jejím podkladě vznikl hypotetický model středověkého vodního mlýna. Pro stavební podobu mlýna bylo vyjma archeologických vědomostí využito především etnografických poznatků.

\section{Středověké vodní mlýny v českých zemích}

Oproti zahraničnímu prostředí jsou české a moravské odkryvy vodních mlýnů doposud takřka ochuzeny o fragmenty mlýnské technologie, jelikož cenné relikty in situ zůstávají nejlépe konzervovány několik metrů pod současným povrchem terénu, ve zvodnělém prostředí. Takovéto ideální pozůstatky je pak možné odhalit až v souvislosti se stavební činností pomocí záchranného archeologického odkryvu (nejnověji např́íklad Górzyńska-Górzyński-Majewski 2011, 59-68; Rollier 2011; Berthold 2008, 173-236). Většina odkryvů v České republice však byla provedena v prostředí nad úrovní vodní hladiny, kde lze očekávat bezmála úplnou redukci organické složky. Mimoto je možné předpokládat u dobře dostupných poloh, kde mlýn zanikal poznenáhlu, rozebírání a odnos cenné mlýnské technologie (srov. Bagniewski-Kubów 1977, 29), což přináší výrazné interpretační limity v důsledku absence relevantních artefaktů (srov. Berthold 2008, 213-214; Völker 2004, 149-151; Westphalen 1997, 215-217; Neyses 1983, 209-221).

\section{Vodní zlatorudný mlýn na řece Otavě (poloha „Pod starou pazdernou“, okr. Písek)}

Nejvýznamnějším záchranným archeologickým výzkumem, který nebyl doposud co do kvality i kvantity zjištěných fragmentů mlýnského zařízení překonán, je odkryv vodního zlatorudného mlýna na řece Otavě (okr. Písek). Při tomto výzkumu uskutečněném J. Kudrnáčem v roce 1967 byly při severovýchodním okraji města Písek v poloze „Pod starou pazdernou“ zjištěny stopy po vodním zlatorudném mlýnu a dalších technických zařízeních sloužících k získávání zlata. Základy stavby tvořily tři trámy o rozměrech $10,58 \times 0,40 \mathrm{~m}, 8,4 \times 0,20 \mathrm{~m}$ a ca $5 \times 0,32 \mathrm{~m}$, mezi nimiž byla vzdálenost $1,21 \mathrm{~m}$ a $3,30 \mathrm{~m}$. Tyto pozůstatky zachycené na břehu Otavy v hloubce $145 \mathrm{~cm}$ pod povrchem byly opatřeny čtyřhrannými dlaby a na koncích hranolo- 


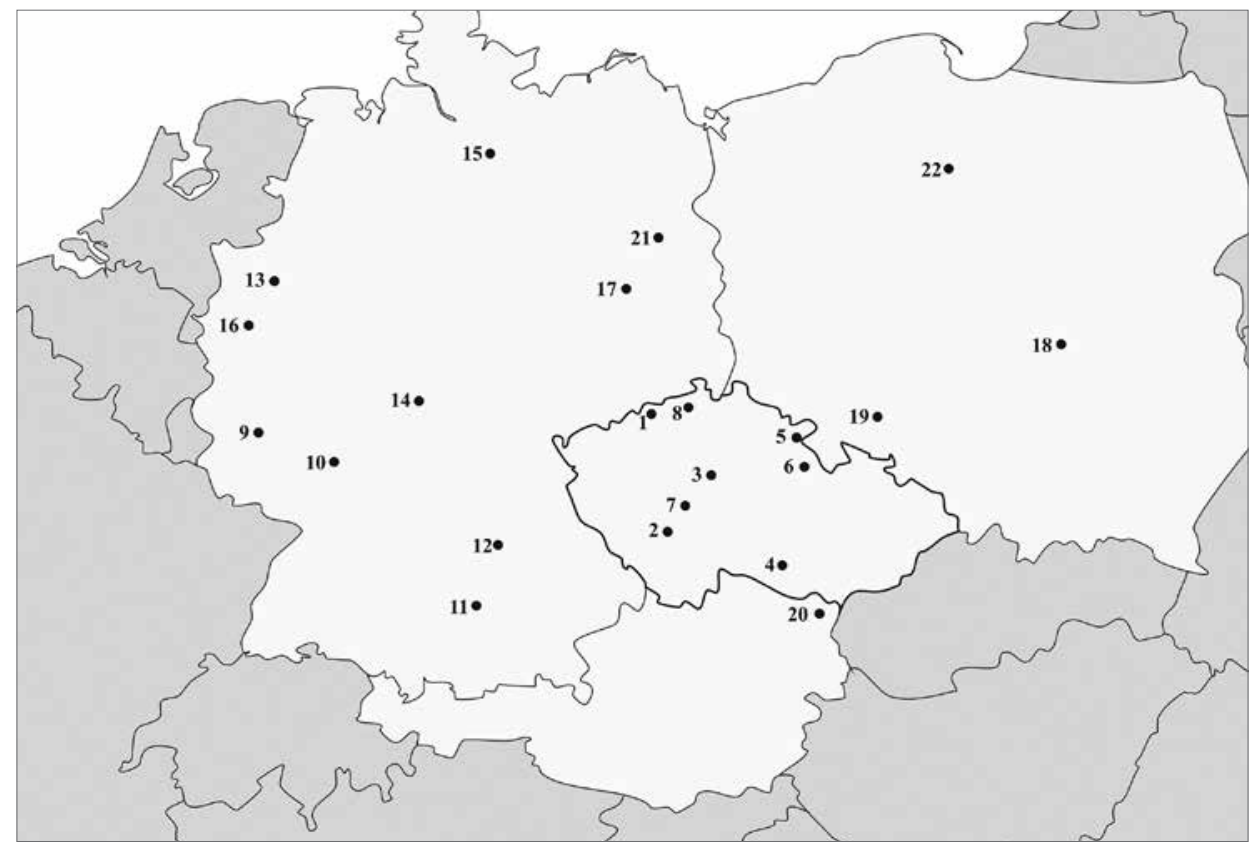

Obr. 1. Výřez mapy střední Evropy. Grafika zobrazuje polohy vybraných archeologických odkryvů situací autory interpretovaných jako středověké vodní mlýny v Čechách na Moravě, Rakousku, Německu a Polsku. Česká republika: 1 - vodní mlýny v Libkovicích (okr. Most), 12./13. - 20. století; 2 - vodní zlatorudný mlýn na Otavě (okr. Písek), po roce 1323; 3 - vodní mlýn ve středověké vsi ve Spáleném (okr. Kolín), 13./14. století; 4 - Vodní mlýn v zaniklé vsi Mstěnice (okr. Břeclav), 14. - 2. polovina 15. století; 5 - vodní mlýn ve Velkém Pořičí (okr. Náchod), 14.-17. století; 6 - vodní mlýn v Jahodově (okr. Rychnov nad Kněžnou), nejpozději počátek 15. století; 7 - vodní mlýn ve vsi Ústupenice (okr. Př́ibram), 1. polovina 15. století; 8 - vodní mlýn Touchořiny čp. 40 (okr. Litoměřice), 15.20. století; Německo: 9 - Lösnich, 5. století; 10 - Gimbsheim, 7.-8. století; 11 - Dasing, 7./8. století; 12 - Großhöbing, 7.-9. století; 13 - Rotbachtal, 832/833; 14 - Fulda, 9. století; 15 - Bardowick, 10.-12. století; 16 - Elfgen, 11.-13. století; 17 - Jüterbog, 12. století; Polsko: 18 - Otoląžka, 13. století; 19 - Ptakowice, 13.-15. století; Rakousko: 20 - Rabensburg an der Thaya, 13.-15. století; Německo: 21 - Ahrensfelde, 1300 - 16. století; Polsko: 22 - Dragacz, 14./15. století. Autorka L. Galusová.

Abb. 1. Kartenausschnitt Mitteleuropa. Die Grafik zeigt die jeweilige Lage ausgewählter archäologischer Freilegungen der von den Verfassern als mittelalterliche Wassermühlen interpretierten Situationen in Böhmen und Mähren, Österreich, Deutschland und Polen. Tschechien: 1 - Wassermühle in Libkovice (Bez. Most), 12./13.-20. Jhdt.; 2 - Golderzwassermühle an der Otava (Bez. Písek), 13./ 14. Jhdt.; 3 - Wassermühle im Mittelalterdorf Ve Spáleném (Bez. Kolín), nach dem Jahr 1323; 4 - Wassermühle in der Dorfwüstung Mstěnice (Bez. Břeclav), 14. - zweite Hälfte 15. Jhdt.; 5 - Wassermühle in Velké Poříčí (Bez. Náchod), 14.-17. Jhdt.; 6 - Wassermühle in Jahodov (Bez. Rychnov nad Kněžnou), spätestens Anfang 15. Jhdt.; 7 - Wassermühle im Dorf Ústupenice (Bez. Př́íbram), erste Hälfte 15. Jhdt.; 8 - Wassermühle Touchořiny Konskriptionsnr. 40 (Bez. Litoměřice), 15.-20. Jhdt.; Deutschland: 9 - Lösnich, 5. Jhdt.; 10 - Gimbsheim, 7.-8. Jhdt.; 11 - Dasing, 7./8. Jhdt.; 12 -Großhöbing, 7.-9. Jhdt.; 13-Rotbachtal, 832/833; 14-Fulda, 9. Jhdt.; 15-Bardowick, 10.12. Jhdt.; 16 - Elfgen, 11.-13. Jhdt.; 17 - Jüterbog, 12. Jhdt.; Polen: 18 - Otoląžka, 13. Jhdt.; 19- Ptakowice, 13.-15. Jhdt.; Österreich: 20 - Rabensburg an der Thaya, 13.-15. Jhdt.; Deutschland: 21 - Ahrensfelde, 1300 - 16. Jhdt.; Polen: 22 - Dragacz, 14./15. Jhdt. Erstellt von L. Galusová.

vitými otvory, jimiž procházely dubové kůly (Kudrnáč-Huml 1969, 37 a Tab. III). Kromě toho byly v trámech v pravidelných rozestupech vyvrtány drobné otvory a do nich zaraženy kolíčky, které původně upevňovaly prkna. Písčité podloží pod stavbou bylo zpevněno kameny a proutím. Pevnost celé konstrukce zvyšovaly nestejně velké kolíky zapuštěné podél trámů do podloží. Úlomky prkének nalezené poblíž základů mlýna interpretoval J. Kudrnáč jako lopatky vodního kola. Vlastní kolo se však z těchto zbytků rekonstruovat nepodařilo. V okolí celého zařízení se vyskytovala křemenná drt' se stopami zlata (jalový odpad), zlomky žulových mlýnských kamenů a stoup. Nalezené mlecí kameny byly vybaveny typickými soustřednými rýhami, které vznikly při rozemílání zlatonosné suroviny a současně měly vsekaný otvor pro kuželici a jamky pro dvouramennou kypřici. Na základě keramiky bylo zařízení datováno do druhé poloviny 13. až první poloviny 14. století (Kudrnáč 1971, 83). Nově vznik mlýna upřesnilo dendrochronologické datování. Zlatorudný mlýn tak byl vystavěn po roce 1323 (Pták-Stehlíková-Koppová-Fröhlich-Šálková-Jiřík, v tisku) Fragmenty lopatek a palečního kola na spodní vodu byly později objeveny také v pískovnách u Vlkova (okr. Tábor; Beneš-Braun 1984, 34, 134) a ve skle- 


\begin{tabular}{|c|c|c|c|c|c|c|c|c|c|c|c|c|}
\hline \multicolumn{3}{|c|}{ Lokalizace a datování } & \multicolumn{2}{|c|}{ Stavba } & \multicolumn{8}{|c|}{ Výstroj mlýna } \\
\hline Stát & Lokalita & $\begin{array}{l}\text { Datování } \\
\text { (století, } \\
\text { příp. rok) }\end{array}$ & $\begin{array}{c}\text { Rozměr } \\
\text { základŭ } \\
\left(\mathrm{m}^{2}\right)\end{array}$ & $\begin{array}{l}\text { Použité } \\
\text { stavební } \\
\text { techniky }\end{array}$ & $\begin{array}{c}\text { Typ } \\
\text { mlýna }\end{array}$ & $\begin{array}{l}\text { Typ } \\
\text { vod- } \\
\text { niho } \\
\text { kola }\end{array}$ & $\begin{array}{l}\text { Rozmerr } \\
\text { vodního } \\
\text { kola } \\
(\mathrm{m})\end{array}$ & $\begin{array}{l}\text { Pa- } \\
\text { leční } \\
\text { kolo }\end{array}$ & $\begin{array}{l}\text { Hř́idel } \\
\text { (prüměr } \\
\text { v m) }\end{array}$ & $\begin{array}{l}\text { Ložis- } \\
\text { ko } \\
\text { hřidele }\end{array}$ & $\begin{array}{l}\text { Průměr } \\
\text { lucerny } \\
(\mathrm{m})\end{array}$ & $\begin{array}{c}\text { Roz- } \\
\text { měr } \\
\text { železi } \\
(\mathrm{m})\end{array}$ \\
\hline Německo & Lösnich & 5 & I & $?$ & $\begin{array}{l}\text { mlýn } \\
\text { s ver- } \\
\text { tikálním } \\
\text { kolem }\end{array}$ & $\begin{array}{l}\text { kolo na } \\
\text { horní } \\
\text { vodu }\end{array}$ & $?$ & ' & ' & ' & I & 1 \\
\hline Německo & Gimbsheim & 7.- -8. & $?$ & $\begin{array}{l}\text { pláto- } \\
\text { vání, } \\
\text { čepování }\end{array}$ & $\begin{array}{l}\text { mlýn } \\
\text { s ver- } \\
\text { tikálním } \\
\text { kolem }\end{array}$ & $\begin{array}{l}\text { kolo na } \\
\text { spodní } \\
\text { vodu }\end{array}$ & 1,8 & / & ' & l & 0,25 & 0,7 \\
\hline Německo & Dasing & 7./8. & 17 & $\begin{array}{l}\text { pláto- } \\
\text { vání, } \\
\text { čepo- } \\
\text { vání, na } \\
\text { drážku }\end{array}$ & $\begin{array}{l}\text { mlýn } \\
\text { s ver- } \\
\text { tikálním } \\
\text { kolem }\end{array}$ & $\begin{array}{l}\text { kolo na } \\
\text { spodní } \\
\text { vodu }\end{array}$ & 1,6 & ano & ' & / & ' & / \\
\hline Německo & Großhöbing & 7. -9 . & $?$ & $\begin{array}{l}\text { pláto- } \\
\text { vání, } \\
\text { čepo- } \\
\text { vání, na } \\
\text { dráźku, } \\
\text { výplet }\end{array}$ & $\begin{array}{l}\text { mlýn } \\
\text { s ver- } \\
\text { tikálním } \\
\text { kolem }\end{array}$ & $\begin{array}{l}\text { kolo na } \\
\text { spodní } \\
\text { vodu }\end{array}$ & $?$ & ' & ' & 1 & 1 & ' \\
\hline Německo & Rotbachtal & $832 / 833$ & 20 & $\begin{array}{l}\text { pláto- } \\
\text { vání, } \\
\text { čepování }\end{array}$ & $\begin{array}{l}\text { mlýn } \\
\text { s ver- } \\
\text { tikálním } \\
\text { kolem }\end{array}$ & $\begin{array}{l}\text { kolo na } \\
\text { spodní } \\
\text { vodu }\end{array}$ & 2,3 & ' & ano (?) & ' & 1 & 1 \\
\hline Německo & Fulda & 9. & ' & $?$ & $\begin{array}{l}\text { mlýn } \\
\text { s ver- } \\
\text { tikálním } \\
\text { kolem }\end{array}$ & $\begin{array}{l}\text { kolo na } \\
\text { spodní } \\
\text { vodu }\end{array}$ & ? & ano & / & / & ' & 1 \\
\hline Německo & Bardowick & $10 .-12$ & ? & $\begin{array}{l}\text { pláto- } \\
\text { vání, } \\
\text { čepování }\end{array}$ & $\begin{array}{l}\text { mlýn } \\
\text { s ver- } \\
\text { tikálním } \\
\text { kolem }\end{array}$ & $\begin{array}{l}\text { kolo na } \\
\text { spodní } \\
\text { vodu }\end{array}$ & $?$ & / & 1 & / & 0,29 & 1 \\
\hline Německo & Elfgen & $11 .-13$. & 35 & $\begin{array}{l}\text { pláto- } \\
\text { vání, } \\
\text { čepování }\end{array}$ & $\begin{array}{l}\text { mlýn } \\
\text { s ver- } \\
\text { tikálním } \\
\text { kolem }\end{array}$ & $\begin{array}{l}\text { kolo na } \\
\text { spodní } \\
\text { vodu }\end{array}$ & 3 & I & / & / & I & / \\
\hline Německo & Jüterbog & 12. & $\min .10$ & $\begin{array}{l}\text { pláto- } \\
\text { vání, } \\
\text { čepo- } \\
\text { vání, na } \\
\text { dráźku, } \\
\text { výplet }\end{array}$ & $\begin{array}{l}\text { mlýn } \\
\text { s ver- } \\
\text { tikálním } \\
\text { kolem }\end{array}$ & $\begin{array}{l}\text { kolo na } \\
\text { spodní } \\
\text { vodu }\end{array}$ & ? & ano & ' & ' & 1 & 1 \\
\hline $\begin{array}{l}\text { Česká } \\
\text { republika }\end{array}$ & Most & $\begin{array}{c}12 . / 13 \\
-20\end{array}$ & / & / & / & / & ' & / & / & / & / & ' \\
\hline Polsko & Otałąžka & 13. & $?$ & $\begin{array}{l}\text { pláto- } \\
\text { vání, } \\
\text { čepování }\end{array}$ & $\begin{array}{l}\text { mlýn } \\
\text { s ver- } \\
\text { tikálním } \\
\text { kolem }\end{array}$ & $\begin{array}{l}\text { kolo na } \\
\text { spodní } \\
\text { vodu }\end{array}$ & $?$ & ' & / & / & ' & 1 \\
\hline
\end{tabular}

Tab. 1. Analýza vodních mlýnů. Data byla získána z dostupné zahraniční a české literatury. Autorka L. Galusová.

Tab. 1. Analyse der Wassermühlen. Die Daten stammen aus der verfügbaren In- und ausländischen Fachliteratur. Erstellt von L. Galusová. 


\begin{tabular}{|c|c|c|c|c|c|c|c|c|c|c|c|c|c|}
\hline Znak, & uvádí absenci na & zu; znak ,? & $\begin{array}{l}\text { uvádí sku } \\
\text { situace }\end{array}$ & $\begin{array}{l}\text { čnost, že v } \\
\text { e takovout }\end{array}$ & $\begin{array}{l}\text { elikos } \\
\text { ovlast }\end{array}$ & $\begin{array}{l}\text { leskrip } \\
\text { ost desl }\end{array}$ & $\begin{array}{l}\text { ru nebyl } \\
\text { iptoru p }\end{array}$ & $\begin{array}{l}\text { nožné z u } \\
\text { ze předpo }\end{array}$ & $\begin{array}{l}\text { lené si } \\
\text { idat. }\end{array}$ & estat & it, příp & ně na zák & Idě dané \\
\hline \multicolumn{14}{|c|}{ Výstroj mlýna } \\
\hline $\begin{array}{c}\text { Typ } \\
\text { kypřice }\end{array}$ & $\begin{array}{c}\text { Rozměr } \\
\text { kypřice }(\mathrm{cm})\end{array}$ & $\begin{array}{l}\text { Materiál } \\
\text { mlecího } \\
\text { kamene }\end{array}$ & $\begin{array}{l}\text { Průměr } \\
\text { středo- } \\
\text { vého } \\
\text { otvoru } \\
\text { mleciho } \\
\text { k. }(\mathrm{cm})\end{array}$ & $\begin{array}{l}\text { Rozměr } \\
\text { mleciho } \\
\text { kamene } \\
(\mathrm{cm})\end{array}$ & Lub & Oškrt & $\begin{array}{l}\text { Násyp- } \\
\text { ný koš }\end{array}$ & $\begin{array}{l}\text { Mlýnská } \\
\text { hranice }\end{array}$ & $\begin{array}{l}\text { Ryb- } \\
\text { nik }\end{array}$ & $\begin{array}{l}\text { Hráz } \\
\text { / jez }\end{array}$ & $\begin{array}{l}\text { Sta- } \\
\text { vidlo }\end{array}$ & Náhon & Citace \\
\hline 1 & ' & pískovec & ' & 100 & ' & ' & 1 & ' & ' & ' & ' & ano & $\begin{array}{c}\text { Neyses } \\
1983\end{array}$ \\
\hline ' & ' & ingimbrit & I & 88 & ' & 1 & I & ' & ' & ' & ' & 1 & $\begin{array}{c}\text { Höck- } \\
\text { mann } \\
1994\end{array}$ \\
\hline $\begin{array}{l}\text { dvoura- } \\
\text { menná }\end{array}$ & $18 \times 4 \times 2$ & bazalt & 6,5 & $60-80$ & ' & ' & ' & ano & ano & 1 & ' & ano & $\begin{array}{c}\text { Czysz } \\
1998\end{array}$ \\
\hline \multirow[t]{3}{*}{$\begin{array}{l}\text { dvoura- } \\
\text { menná }\end{array}$} & ' & $?$ & I & ' & ' & ' & ' & ' & ' & ano & ano & I & $\begin{array}{c}\text { Herzig- } \\
\text { Liebert- } \\
\text { Nadler } \\
1998\end{array}$ \\
\hline & / & bazalt & ' & ' & ' & ' & ' & ' & ' & / & ' & ano & $\begin{array}{l}\text { Tutlies } \\
2006\end{array}$ \\
\hline & 1 & $?$ & I & ' & 1 & ' & ' & 1 & ' & ' & ' & I & $\begin{array}{l}\text { Kind } \\
2007\end{array}$ \\
\hline $\begin{array}{l}\text { dvou- } \\
\text { i čtyřra- } \\
\text { menná }\end{array}$ & $13 \times 6-3 \times 2,5$ & $\begin{array}{c}\text { pískovec, } \\
\text { bazalt }\end{array}$ & 6,5 & $70-90$ & I & ano & / & ' & ' & I & I & I & $\begin{array}{l}\text { Krüger } \\
1934\end{array}$ \\
\hline $\begin{array}{l}\text { dvoura- } \\
\text { menná }\end{array}$ & $24 \times 6 \times 3,5$ & bazalt & 8 & 100 & 1 & ano & I & I & 1 & I & ' & ano & $\begin{array}{l}\text { Berthold } \\
2008\end{array}$ \\
\hline $\begin{array}{l}\text { dvoura- } \\
\text { menná }\end{array}$ & ' & bazalt & 1 & ' & ' & ' & ' & ' & ' & ano & ano & ano & $\begin{array}{l}\text { Schwarz- } \\
\text { länder } \\
2003\end{array}$ \\
\hline 1 & 1 & I & I & ' & 1 & ' & ' & 1 & ' & 1 & ' & ano & $\begin{array}{c}\text { Nováček- } \\
\text { Vařeka } \\
1994\end{array}$ \\
\hline $\begin{array}{l}\text { vlaštov- } \\
\text { čí ocas }\end{array}$ & 1 & pískovec & I & $70-80$ & ' & 1 & ' & 1 & ' & 1 & ' & ano & $\begin{array}{c}\text { Bender } \\
1974\end{array}$ \\
\hline
\end{tabular}




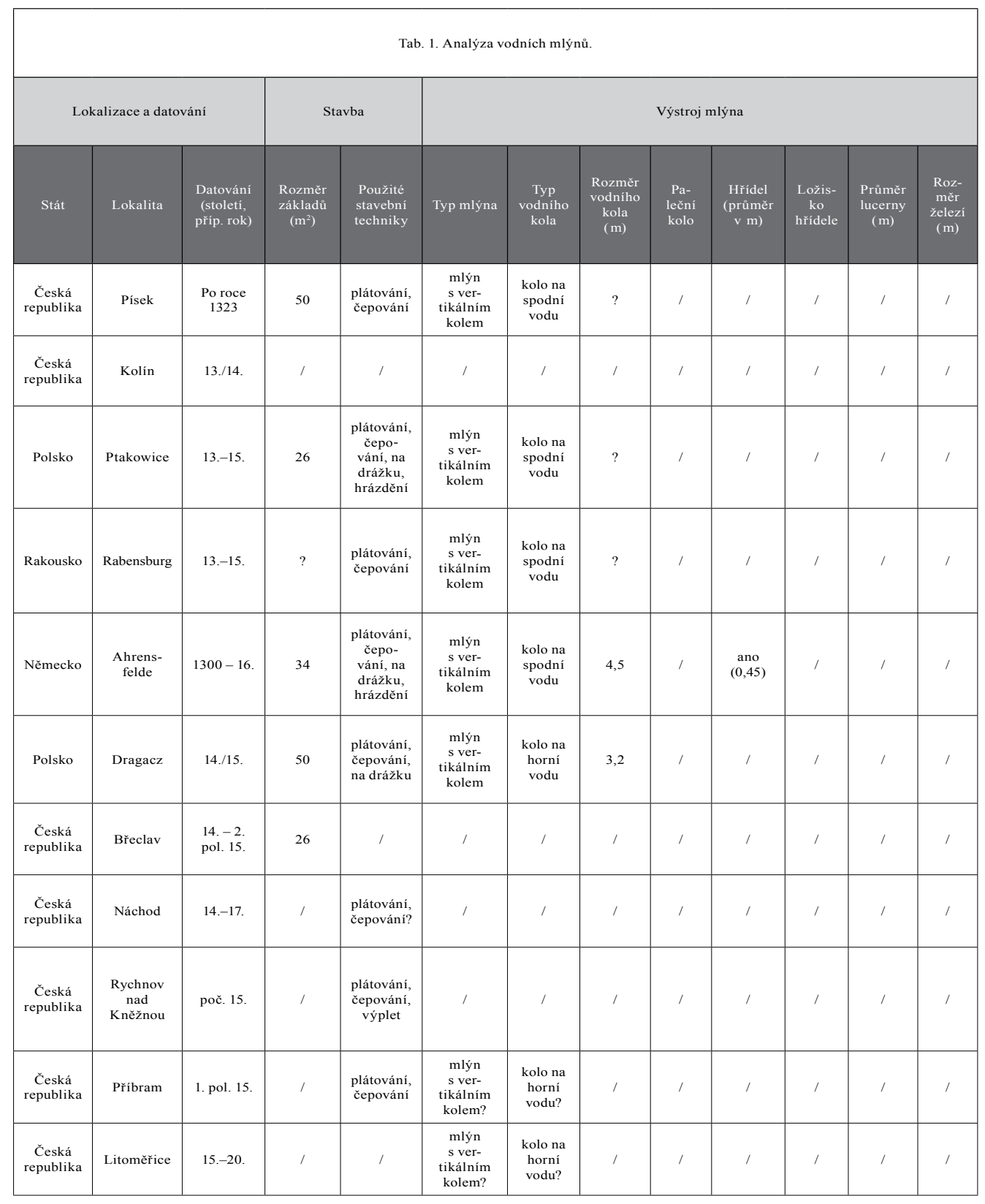

Tab. 1. Analýza vodních mlýnů. Data byla získána z dostupné zahraniění a české literatury. Autorka L. Galusová.

Tab. 1. Analyse der Wassermühlen. Die Daten stammen aus der verfügbaren In- und ausländischen Fachliteratur. Erstellt von L. Galusová. 


\begin{tabular}{|c|c|c|c|c|c|c|c|c|c|c|c|c|c|}
\hline \multicolumn{14}{|c|}{ Výstroj mlýna } \\
\hline $\begin{array}{c}\text { Typ } \\
\text { kyprice }\end{array}$ & $\begin{array}{l}\text { Rozměr } \\
\text { kypřice } \\
(\mathrm{cm})\end{array}$ & $\begin{array}{l}\text { Materiál } \\
\text { mlecího } \\
\text { kamene }\end{array}$ & $\begin{array}{l}\text { Prûmměr } \\
\text { středo- } \\
\text { vého } \\
\text { otvoru } \\
\text { mlecího } \\
\mathrm{k} .(\mathrm{cm})\end{array}$ & $\begin{array}{c}\text { Rozměr } \\
\text { mlecího } \\
\text { kamene } \\
(\mathrm{cm})\end{array}$ & Lub & Oškrt & $\begin{array}{l}\text { Násyp- } \\
\text { ný koš }\end{array}$ & $\begin{array}{l}\text { Mlýnská } \\
\text { hranice }\end{array}$ & $\begin{array}{l}\text { Ryb- } \\
\text { nik }\end{array}$ & $\begin{array}{l}\text { Hráz } \\
/ \text { jez }\end{array}$ & $\begin{array}{l}\text { Sta- } \\
\text { vidlo }\end{array}$ & Náhon & Citace \\
\hline $\begin{array}{l}\text { dvoura- } \\
\text { menná }\end{array}$ & I & žula & 1 & 85 & I & I & ' & / & / & 1 & ' & ano & $\begin{array}{c}\text { Kudrnáč-Huml } \\
1969\end{array}$ \\
\hline ' & I & 1 & 1 & I & 1 & I & I & I & ano & I & ' & ano & $\begin{array}{l}\text { Klápště 1978; } \\
\text { Maříková 2005 }\end{array}$ \\
\hline $\begin{array}{l}\text { dvoura- } \\
\text { menná }\end{array}$ & / & pískovec & ' & ' & ' & ' & ? & 1 & ano & I & ' & ano & $\begin{array}{l}\text { Bagniewski- } \\
\text { Kubów } 1977\end{array}$ \\
\hline & I & $?$ & I & I & I & I & I & I & 1 & I & I & ano & $\begin{array}{l}\text { Adler-Hundsbich- } \\
\text { ler1981 }\end{array}$ \\
\hline $\begin{array}{l}\text { dvoura- } \\
\text { menná }\end{array}$ & / & bazalt & / & 120 & I & / & / & I & / & ano & ano & ano & Kellermann 1953 \\
\hline $\begin{array}{l}\text { dvoura- } \\
\text { menná }\end{array}$ & / & pískovec & I & 80 & I & I & I & I & ano & I & ano & ano & $\begin{array}{l}\text { Górzyńska-Gór- } \\
\text { zyński-Majewski } \\
2011\end{array}$ \\
\hline I & / & durbachit & I & ? & / & / & I & I & ano & 1 & ' & I & Nekuda 2006 \\
\hline ' & ' & $?$ & $?$ & ? & I & ' & / & ' & I & ano? & ' & I & Koštál 2012 \\
\hline I & ' & slepenec? & ? & ? & I & 1 & 1 & 1 & ano & ano & $?$ & ano & $\begin{array}{c}\text { Beková-Dragoun } \\
\text { 2004; Dragoun } \\
2009\end{array}$ \\
\hline I & / & ' & I & 1 & / & I & / & 1 & ano & l & ' & / & $\begin{array}{c}\text { Kašpar-Smejtek- } \\
\text { Vařeka } 1999\end{array}$ \\
\hline I & 1 & $\begin{array}{l}\text { jemno- } \\
\text { zrnný } \\
\text { slepenec }\end{array}$ & ? & ? & ' & ' & I & ' & ano & I & ' & 1 & Galusová 2014 \\
\hline
\end{tabular}


pě domu čp. 153 v Karlově ulici v Praze (Štěpán-Urbánek-Klimešová 2008, 316). Tyto vodní motory však vzhledem k nálezovým okolnostem není možné datovat. Dále lze uvést pozůstatky nejspíše středověkých vodních kol z Př́íšovic (na horní vodu) a z Veselí nad Lužnicí o průměru přibližně 3 m (na spodní vodu; Dvořáková-Merta 2005, 113, 118-119).

\section{Předpokládaný vodni mlýn ve středověké vsi ve Spáleném (k. ú. Vyžlovka, okr. Kolín)}

Archeologický výzkum v zaniklé středověké vesnici ve Spáleném, který proběhl v letech 1978 a 1990, odhalil terénní útvary, zbytky zdí a keramiky, které byly interpretovány J. Klápštěm jako pozůstatky zaniklého středověkého vodního mlýna. V terénu bylo možné identifikovat prŕvod vody na kolo, který autor výzkumu situuje k patě rybniční hráze, a dále též odpadní koryto, které pokračovalo až za korunu druhé rybniční hráze (Smetánka-Klápště 1981, 416-458). Do hráze byla při jejím dolním okraji zapuštěna oboustranně lícovaná zed' z lomového kamene o tloušt'ce zdiva $125 \mathrm{~cm}$ s kolmo přisazenou příčkou o tloušt'ce $115 \mathrm{~cm}$. Obdobnou situaci zachytila zjištovací sonda také při horním okraji hráze. Nalezené zdi patrně sloužily pouze ke zpevnění sypaného tělesa hráze. Objekt byl datován na základě keramiky do průběhu 13. století a lze jej spojit s počátky zde vysazeného středověkého sídliště (Klápště 1978, 445, 446; Maříková 2005, 89-148). Bohužel zde nebyly zjištěny žádné relevantní pozůstatky stř̌edověkého vodního mlýna, dle nichž by bylo možné jeho existenci jednoznačně prokázat.

\section{Předpokládané vodní mlýny v Libkovicích na Mostecku (k. ú. Libkovice, okr. Most)}

Záchranný archeologický výzkum ve vsi Libkovice na Mostecku započal již na podzim roku 1991 a pokračoval v letech 1992 a 1993. Odkryv byl vyvolán potřebou těžby hnědého uhlí, stejně jako v mnohých dalších vesnicích ležících v hnědouhelných pánvích. Nákladný archeologický výzkum ve spolupráci s dalšími obory řešil komplexní studium jak vlastní vesnice, tak jejího katastru od počátků sídelní aktivity v neolitu až po definitivní zánik této části kulturní krajiny.

Výzkum se zaměřil především na střední část vsi, kde bylo možné očekávat nejbohatší archeologické situace a nejuspokojivěji řešit kladené otázky spojené se studiem osídlení ve středověku, novověku a transformace sídla v průběhu první poloviny 19. století. Nejstarší doklady středověkého osídlení byly nalezeny $\mathrm{v}$ prostoru návsi a parcel na pravém břehu potoka a byly datovány do konce 12 . století až první třetiny 13. století. Ze zjištěných objektů lze uvést kupříkladu část nadzemního domu se zahloubeným ohništěm, množství jam rozličného tvaru a velikosti a především mělký žlab, který zřejmě představuje starší fázi vrcholně stř̌edověkého až novověkého mlýnského náhonu (Nováček-Vařeka 1993, 49-51; 1994, 223). Je zajisté škoda, že libkovický výzkum nebyl doposud řádně publikován.

\section{Předpokládaný vodni mlýn ve vsi Ústupenice (k. ú. Doubravice, okr. Př́bram)}

Roku 1997 byly během záchranného archeologického výzkumu zaniklého středověkého sídlištního komplexu pod rybniční hrází zjištěny relikty, které byly interpretovány jako pozůstatky pozdně středověkého nejspíše vodního mlýna sloužícího jako součást hospodářského zázemí tohoto areálu. Šlo o vícedílný dřevěný objekt stojící na kamenné podezdívce, zastřešený pálenými taškami. Uvnitř byla zachycena dřevěná podlaha, stolní a kuchyňská keramika z první poloviny 15 . století a množství vypálené mazanice svědčící pro zánik stavby požárem. Sousední cihlový objekt $\mathrm{s}$ dřevěným patrem byl interpretován jako sýpka. Celkové rozměry staveb ani podoba technického zařízení mlýna nemohly být kvůli omezenému rozsahu výzkumu zjištěny. Vzhledem k malé vydatnosti vodního toku a terénní konfiguraci však autoři výzkumu předpokládají, že šlo o podhrázský mlýn poháněný horní vodou vedenou z rybníka dřevěnými vantroky (Kašpar-Smejtek-Vařeka 1999, 101-109). Odkryté relikty byly ovšem interpretovány jako pozůstatky tohoto typu památky pouze dle své polohy pod hrází již zaniklého rybníka. Mimo tyto logické úvahy však pro danou interpretaci bohužel nesvědčí žádný relevantní artefakt či archeologická situace. 
Vodní mlýn v zaniklé vsi Mstěnice (k. ú. Hrotovice, okr. Břeclav)

V prostoru zaniklé středověké vsi Mstěnice interpretoval Rostislav Nekuda objekt z lomového kamene o rozměrech $5 \times 5,2$ m jako vodní mlýn na horní vodu ze 14 . století (obr. 2). Od roku 1999 byl v areálu mlýna zahájen archeologický odkryv, který odhalil komplex pozůstatků staveb. Jde o pozůstatky výše jmenované budovy mlýna z lomového kamene, obytného domu o rozměrech $11 \times 6 \mathrm{~m}$ a sýpky $3,7 \times 3,1 \mathrm{~m}$. Zásobu vody pro provoz mlýna zajištoval přibližně 100 metrů vzdálený rybník, zbudovaný na blízkém potoce. Př́ívod vody ke mlýnu však nebyl nalezen. Dvoupatrová kamenná mlýnice orientovaná sever-jih, členěná do dvou místností o rozměrech $5 \times 1,5 \mathrm{~m}$ a $4 \times 2 \mathrm{~m}$, obsahovala starší konstrukce, dle nichž R. Nekuda předpokládá, že tento mlýn založený ve druhé polovině 14 . století měl nejspíše svého předchůdce s orientací východ-západ (viz obr. 2). Podle R. Nekudy byly v prostoru odkrytého komplexu vodního mlýna roztroušeny fragmenty žernovů, mlecích kamenů, kamenné brusy a moždír. Objekt zanikl ve druhé polovině 15. století společně se vsí v důsledku válečných událostí (Nekuda 2006, 185191). Bohužel je doposud postrádána ucelenější studie, která by zahrnovala detailní zpracování mlecích kamenů s kvalitní obrazovou prŕlohou ve vztahu k vodnímu mlýnu, řešící kupř́ikladu absenci či prezenci křesu, stopy po vsekání otvorů pro uchycení kypřice (srov. Jaccottey-Farget 2011, 51-68), případně technologické stopy (srov. Berthold 2009, 202).

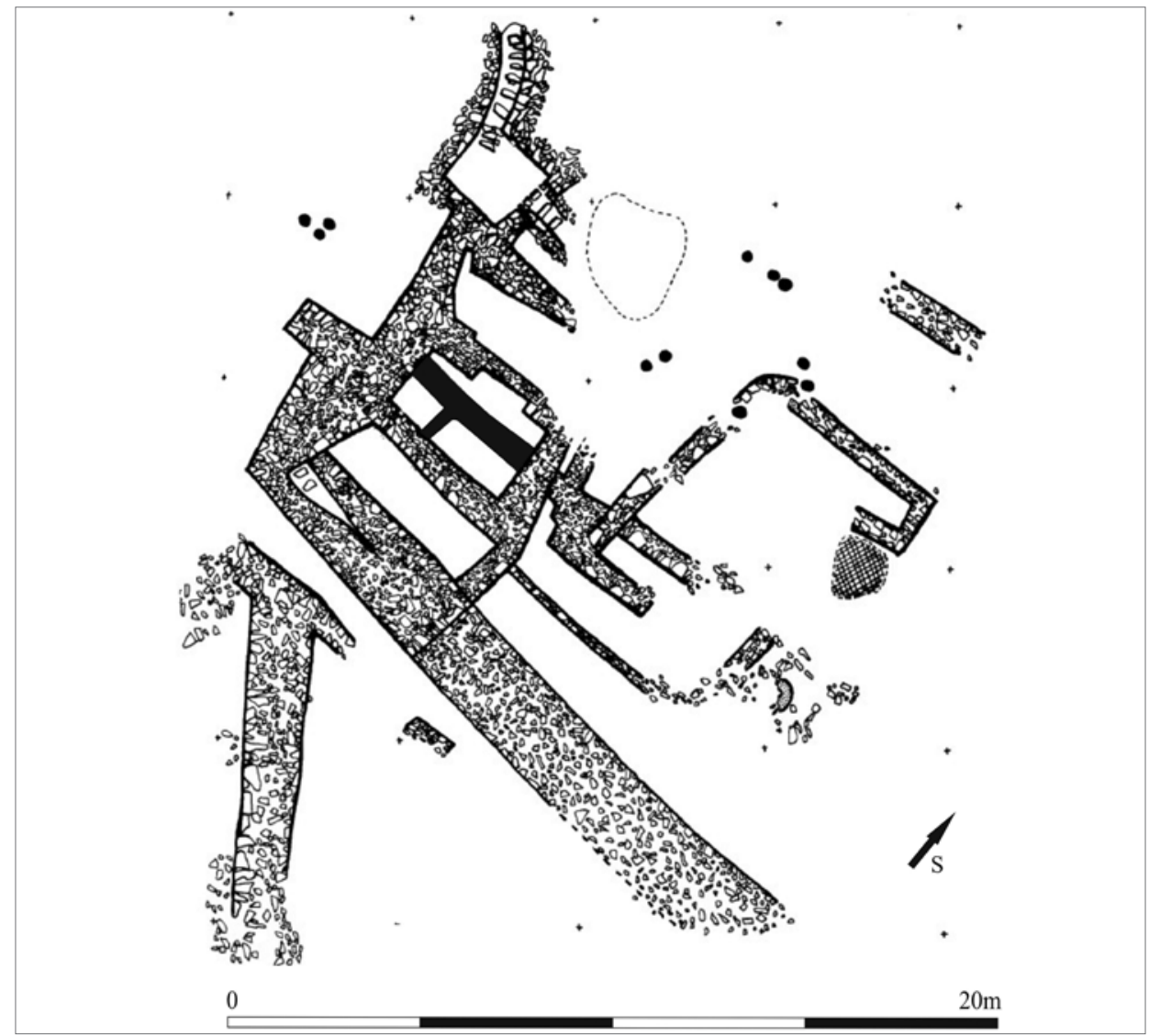

Obr. 2. Mstěnice, k. ú. Hrotovice, okr. Břeclav. Pozůstatky stavby zjištěné při záchranném archeologickém výzkumu v zaniklé vsi Mstěnice, interpretované jako vodní mlýn. Mlýnská budova v levé části plánku. Černé zdivo vyznačuje předpokládanou starší fázi mlýna odkrytou v mlýnici. Podle Nekuda 2006, 131.

Abb. 2. Mstěnice, Katastergebiet Hrotovice, Bezirk Břeclav, Südmähren. Überreste eines bei einer Rettungsgrabung in der Dorfwüstung Mstěnice entdeckten und als Wassermühle interpretierten Baus. Das Mühlenhaus befindet sich im linken Teil der Planskizze. Das schwarze Mauerwerk bezeichnet die vermutlich ältere, im Mühlenhaus freigelegte Phase der Mühle. Nach Nekuda $2006,131$. 


\section{Vodní mlýn v Jahodově ( $k$. ú. Jahodov, okr. Rychnov nad Kněžnou)}

Záchranný archeologický výzkum provedený na katastrálním území obce Jahodov v okrese Rychnov nad Kněžnou v květnu roku 2003 v souvislosti s budováním protipovodňového opatření v prostoru pravobřežního přítoku Jahodovského potoka odhalil fragmenty dřev a archeologických situací, které byly interpretovány jako pozůstatky středověkého vodního mlýna s jeho zázemím, datované dle keramických nálezů nejpozději do počátku 15. století. V údolí širokém přibližně $60 \mathrm{~m}$ byla vytyčena sondáž skládající se $\mathrm{z}$ několika na sebe kolmých řezů o šíři $60 \mathrm{~cm}$ a hloubce $40-50 \mathrm{~cm}$. Na dně výkopů bylo zjištěno opukové podloží, na němž se nalézala vrstva rybničního bahna s jílem. Tato jednotka byla upravena pro stavbu dřevo-hlinitého jezu a vydřeveného náhonu zachyceného $\mathrm{v}$ délce 0,8 až $0,9 \mathrm{~m}$ o šíři 1,2 až $1,6 \mathrm{~m}$ se zahloubením $0,4 \mathrm{~m}$. Dřevěné prvky byly pojeny plátováním a čepováním. Mimo tyto pozůstatky byla zjištěna aplikace doplňkové techniky proutěného výpletu. Tento proutěný fragment byl však silně archeologizován. V náhonu byly nalezeny zlomky kamenů, které autoři výzkumu označili za mlecí kameny vodního mlýna. V blízkosti jmenovaných kamenných zlomků byla zjištěna též kamenná stoupa, která byla užíána k výrobě krup. Doposud však v publikovaném materiálu nebyly tyto artefakty blíže specifikovány. Kupříkladu schází popis případných stop opracování či technologických stop, na jejichž základě by bylo možné prokázat užívání těchto artefaktů v mlecím složení. Pozůstatky staveb nebyly nalezeny. Autoři výzkumu se domnívají, že u Jahodova byla zachycena okrajová část situace zázemí středověkého vodního mlýna, jehož vlastní pozůstatky nejspíše zůstaly archeologickým odkryvem nedotčeny (Beková-Dragoun 2004, 25; Dragoun 2009, 10-11). Lze doufat, že výzkum bude v co nejbližší době uspokojivě publikován s dokumentací, fotografiemi a analýzami dotčených artefaktů.

\section{Předpokládaný vodní mlýn ve Velkém Pořiči (k. ú. Velké Pořičí, okr. Náchod)}

Od roku 2010 do průběhu října roku 2012 probíhal záchranný archeologický výzkum ve Velkém Poříčí, který odhalil při bagrování odlehčovacího koryta řeky Metuje $\mathrm{v}$ hloubce asi 2,5 m staré říční koryto s dřevěnými piloty, spojenými v jejich spodní části komorovou konstrukcí. Jelikož nemohla být z dřevěných pozůstatků získána žádná relevantní dendrochronologická data, musela být situace datována pouze za pomoci zlomků keramiky, a to do 14.-17. století. Před započetím výzkumu byl dle J. Koštála vyzvednut „mlýnský“ kámen, který však bohužel nebyl autorem blíže specifikován. J. Koštál předpokládá, že dřevěné zbytky a nález mlecího kamene poukazují na objev pozůstatků středověkého až novověkého vodního mlýna (Koštál 2012, 2). Interpretace na základě jmenovaných indicií může být zavádějící. Jediný fragment mlecího kamene mohl být s lokalitou spojen neintencionálně (kupř́íkladu v důsledku říčních akumulačních procesů) a dř̌evěné pozůstatky mohou představovat základy jiného druhu nemovité památky. K potvrzení či vyvrácení uvedené interpretace by bylo třeba kvalitnější analýzy dané situace a řádné publikace.

\section{Vodní mlýn Touchořiny čp. 40 (k. ú. Touchořiny, okr. Litoměřice)}

Záchranný archeologický výzkum na parcele vodního mlýna Touchořiny čp. 40 prokázal stavební aktivity v tomto prostoru nejpozději na sklonku pozdního středověku. Pozdně středověká fáze byla datována výhradně pomocí zlomků keramiky ze sondy 1, sektoru VI (obr. 3). Jednotky 108 a 109, které obsahovaly výhradně středověké fragmenty keramiky, byly zjištěny v ploše přibližně $2 \mathrm{~m}^{2}$. Šlo o pozůstatky pozdně středověkých podlah, které nebyly odstraněny mladšími zásahy. Vrstva 108 se od jihu vázala na fragment konstrukce K115 (o rozměrech 2,12× $0,45 \times 0,7 \mathrm{~m}$ ) jdoucí ve směru východ-západ (obr. 4), která zpevňovala jílovito-kamenité akumulační těleso Lučního potoka a vymezovala původně středověký obytný prostor. Silně omletý zlomek mlecího kamene $\mathrm{z}$ pevného silicifikovaného nevytř́iěného pískovce až slepence o velikosti $38 \times 30 \mathrm{~cm}$ a síle $7 \mathrm{~cm}$ ze sondy 2 se zbytky viditelného křesu, který byl nalezen ve zdivu sklepa vystavěného nejpozději v raném novověku, a středověké keramické nálezy ze sondy 1 , 


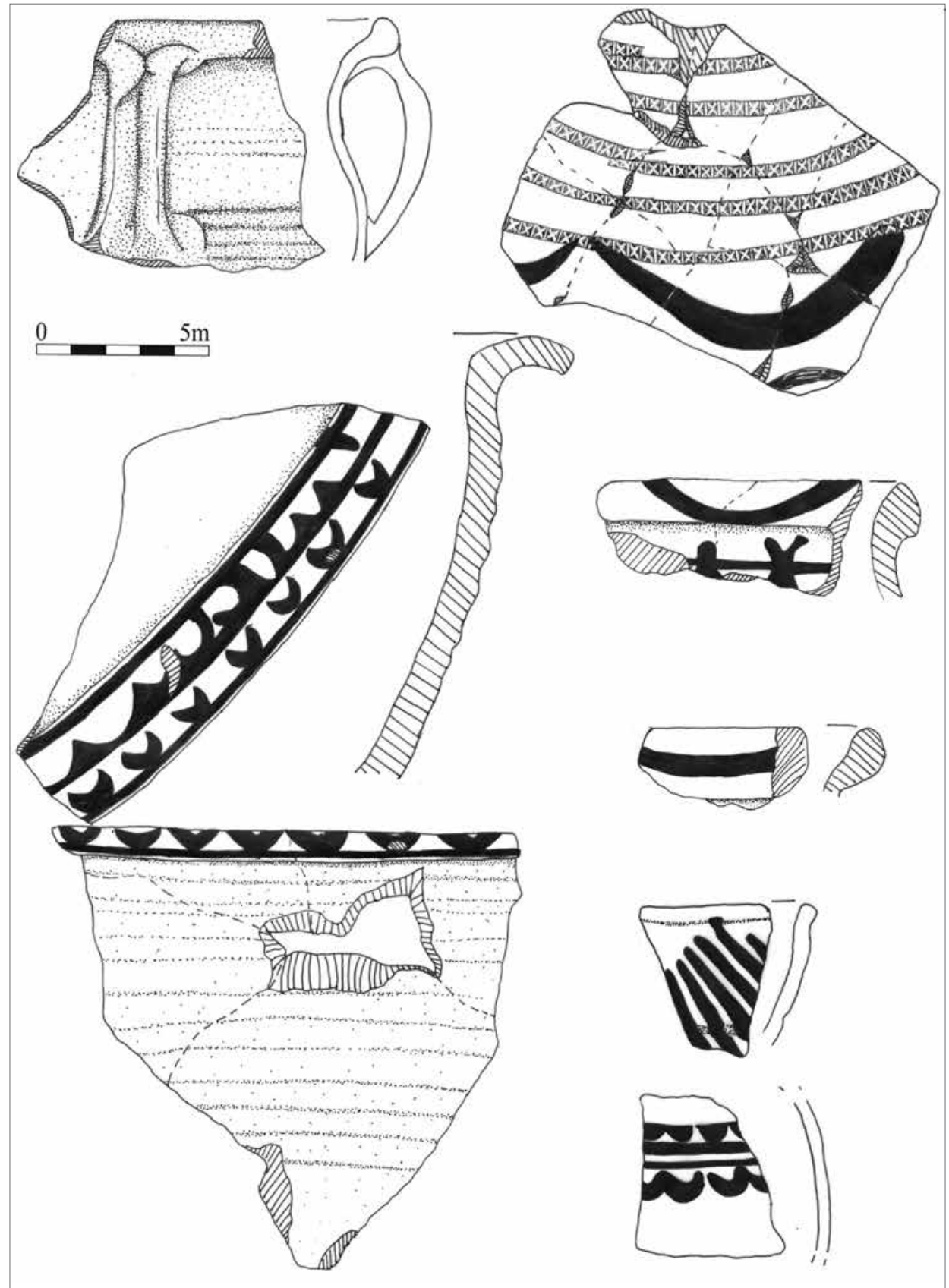

Obr. 3. Touchořiny čp. 40, k. ú. Touchořiny, okr. Litoměřice. Pozdně stř̌edověká keramika ze sondy S1, sektoru VI, odhalená při záchranném archeologickém výzkumu v prostoru vodního mlýna. Kresba V. Rohanová.

Abb. 3. Touchořiny Konskriptionsnr. 40, Katastergebiet, Bezirk Litoměřice, Nordwestböhmen. Spätmittelalterliche Keramik aus Sondierschnitt S1, Sektor VI, freigelegt durch eine archäologische Rettungsgrabung im Bereich der Wassermühle. Zeichnung V. Rohanová. 


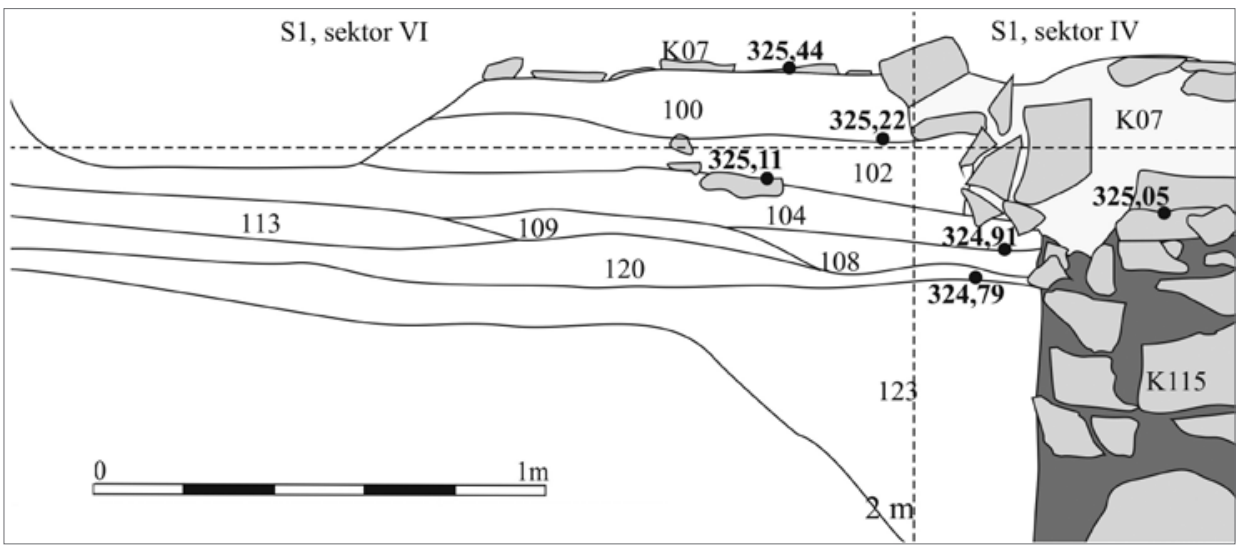

Obr. 4. Touchořiny čp. 40, k. ú. Touchořiny, okr. Litoměřice. Stratigrafický vztah konstrukce K115 a jednotek 104 a 108 , sonda S1, sektor VI, částečně sektor IV. Tmavě - pozdně středověká konstrukce K115 pojená na jíl; světle žlutě - novověká, mělce založená konstrukce K07 pojená maltou. Vrstvy 120 a 123 již představují podloží. Digitalizace L. Galusová.

Abb. 4. Touchořiny Konskriptionsnr. 40. Katastergebiet, Bezirk Litoměřice, Nordwestböhmen. Stratigraphische Beziehung zwischen Konstruktion K115 und den Einheiten 104 und 108. Sondierschnitt S1, Sektor VI, teilweise Sektor IV. Dunkel - lehmgebundene spätmittelalterliche Konstruktion K115; hellgelb - mörtelgebundene neuzeitliche Konstruktion K07 mit flacher Gründung. Bei den Schichten 120 und 123 handelt es sich bereits um den Untergrund. Digitalisierung L. Galusová.

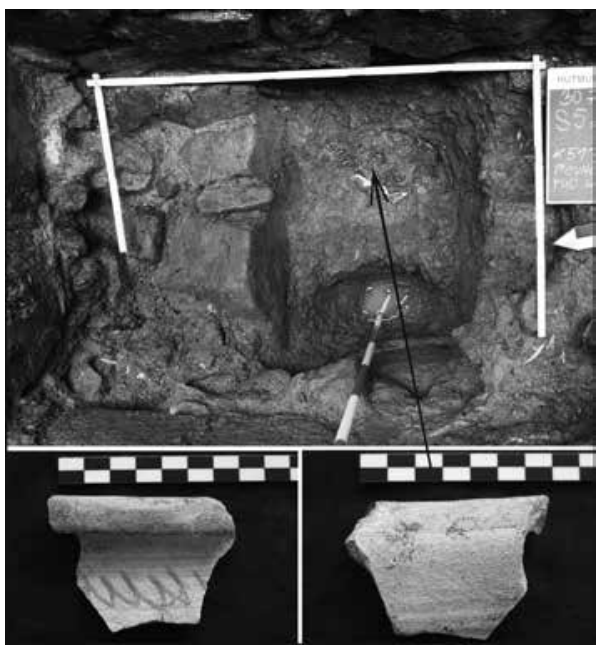

Obr. 5. Touchořiny čp. 40 , k. ú. Touchořiny, okr. Litoměřice. Pohled do žlabu pro paleční kolo, sonda S5. Na podloží se nalézala v tenké vrstvě jednotka 507 se zlomky pozdně středověké až raně novověké keramiky. Konstrukce v levé části snímku je nejspíše starší fází žlabu pro paleční kolo. Foto L. Galusová. Abb. 5. Touchořiny Konskriptionsnr. 40. Katastergebiet, Bezirk Litoměřice, Nordwestböhmen. Blick in die für das Zahnrad vorgesehene Rinne, Sondierschnitt S5. Auf dem Untergrund befindet sich in einer schmalen Schicht die Einheit 507 mit Bruchstücken spätmittelalterlicher bis frühneuzeitlicher Keramik. Bei der Konstruktion im linken Teil der Aufnahme handelt es sich höchstwahrscheinlich um die ältere Phase der für das Zahnrad vorgesehenen Rinne. Foto L. Galusová. sektoru VI, dokládají hlubokou kontinuitu funkce mlýna nejpozději do průběhu druhé poloviny 15. století.

$\mathrm{K}$ přestavbě objektu došlo $\mathrm{v}$ raném novověku, kdy mlýn nabyl trojdílné dispozice a stavba byla cele realizována již v ploše současného objektu (obr. 5, 6; Galusová 2014, 88). Síň byla vydlážděna opukovou dlažbou a nad středověkou konstrukcí vznikla mělce založená mladší novověká zed' (K07), orientovaná v opačném smyslu, a stratigraficky tak překryla starší situace (viz obr. 4). Následující stavební úpravy již souvisely s rozšiřováním objektu a modernizací mlýna $\mathrm{v}$ průběhu 19 . a 20 . století, kdy objekt dosáhl rozměru 13,8 $\times 25 \mathrm{~m}$. Oproti starším situacím bylo z této vývojové etapy získáno relativně velké množství fragmentů mlýnské technologie.

\section{Stř̌edověké vodní mlýny v zahraničí}

\subsection{Německo}

Předpokládaný vodní mlýn u Lösnichu (okr. Bernkastel-Wittlich, Porýni-Falc)

Archeologický výzkum ve skalním masivu nedaleko města Trier v německém Lösnichu odhalil pozůstatky technologie užívající vodní sílu, datované do 5. století. A. Neyses na základě vseků do skály a obroušeného skalního masivu po užívání vodní síly předpokládá dvě vertikální vodní kola, umístěná v kaskádě za sebou. Zda šlo o lopatníky či korečníky, není známo. Účel tohoto pozdně antického zařízení není taktéž jednoznačně prokázán. Lze uvažovat 


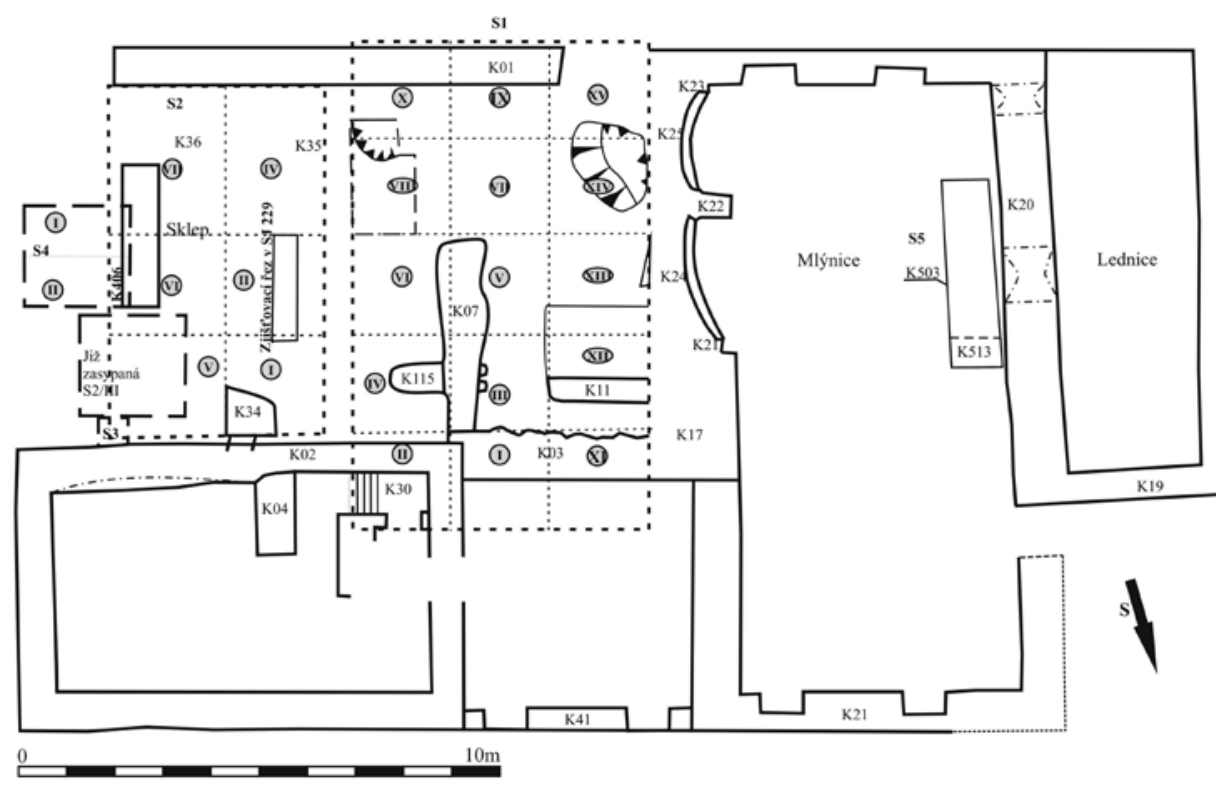

Obr. 6. Touchořiny čp. 40, k. ú. Touchořiny, okr. Litoměřice. Plán vodního mlýna Touchořiny čp. 40 s rozvrženou sondáží. Sonda S1 ležela ve středové části objektu, S2 odhalila sklepní prostor v obytné části mlýna (východní část), S3 se nalézala při konstrukci Ko2, S4 umístěná ve východní části jako jediná řešila i exteriér parcely vodního mlýna a $S 5$ se nalézala v mlýnici. Odkryv starších jednotek v S5 byl realizován pouze v prostoru žlabu pro paleční kolo (konstrukce K503). Digitalizace L. Galusová.

Abb. 6. Touchořiny Konskriptionsnr. 40. Katastergebiet, Bezirk Litoměřice, Nordwestböhmen. Planskizze der Wassermühle Touchořiny Konskriptionsnr. 40 mit Verteilung der Sondiergrabungen. Sondierschnitt S1 lag im mittelalterlichen Teil des Objekts, Sondierschnitt S2 legte den Kellerraum im Wohnteil der Mühle frei (östlicher Teil), Sondierschnitt S3 befand sich an Konstruktion K02, der im östlichen Teil gelegene Sondierschnitt S4 betraf als einziger auch den außerhalb der Parzelle der Wassermühle liegenden Bereich, und Sondierschnitt S5 befand sich im Mühlenhaus. Die Freilegung der älteren Einheiten in Sondierschnitt S5 erfolgte lediglich im Bereich der für das Zahnrad vorgesehenen Rinne (Konstruktion K503). Digitalisierung L. Galusová.

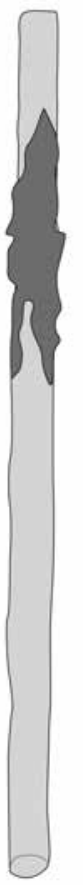

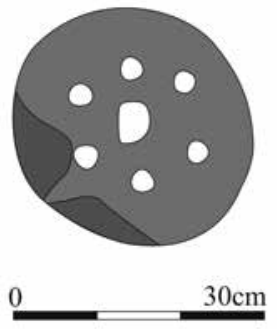

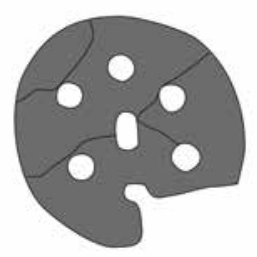

o vodním mlýnu, př́ípadně o vodní pile na kámen apod. (Neyses 1983, 209-221).

\section{Lodní mlýn u Gimbsheimu (okr. Alzey-Worms, Porýni-Falc)}

Významným objevem na německé půdě je nález pozůstatků raně stř̌edověkého lodního mlýna v zaniklém korytě řeky Rýn u Gimbsheimu. Výzkum prrispěl cennými poznatky k vnitřnímu vybavení mlecího soustrojí. Bylo nalezeno jedno kompletní složení mlecích kamenů lodního mlýna o průměru $80 \mathrm{~cm}$, část železí, přičemž jeho délka dosahovala $70 \mathrm{~cm}$, a fragment cévníku o průměru $25 \mathrm{~cm}$ se šesti cévy (obr. 7). Vše náleží jednomu typu lod-

Obr. 7. Gimbsheim, okr. Alzey-Worms, Německo. Artefakty zjištěné při záchranném archeologickém výzkumu v zaniklém korytě řeky Rýn u Gimbsheimu. Jde o část železí a fragment cévníku se šesti cévy. Digitalizace L. Galusová podle Höckmann 1994, 207.

Abb. 7. Gimbsheim, Landkreis Alzey-Worms, Deutschland. Bei einer archäologischen Rettungsgrabung im Flussbett des Altrheins bei Gimbsheim gefundene Artefakte. Dabei handelt es sich um den Teil eines Mühleisens und um das Fragment eines Stockrades mit sechs „Triebstöcken“. Digitalisierung L. Galusová nach Höckmann 1994, 207. 
ního mlýna s vertikálním kolem, dle rekonstrukce patrně o průměru $1,8 \mathrm{~m}$. Z lodního mlýna, datovaného do 7.-8. století, byly nalezeny zbytky lodí, podlah a lávky mezi loděmi. Na kovové ose (železí) byly objeveny stopy dřeva (Höckmann 1994, 191-209).

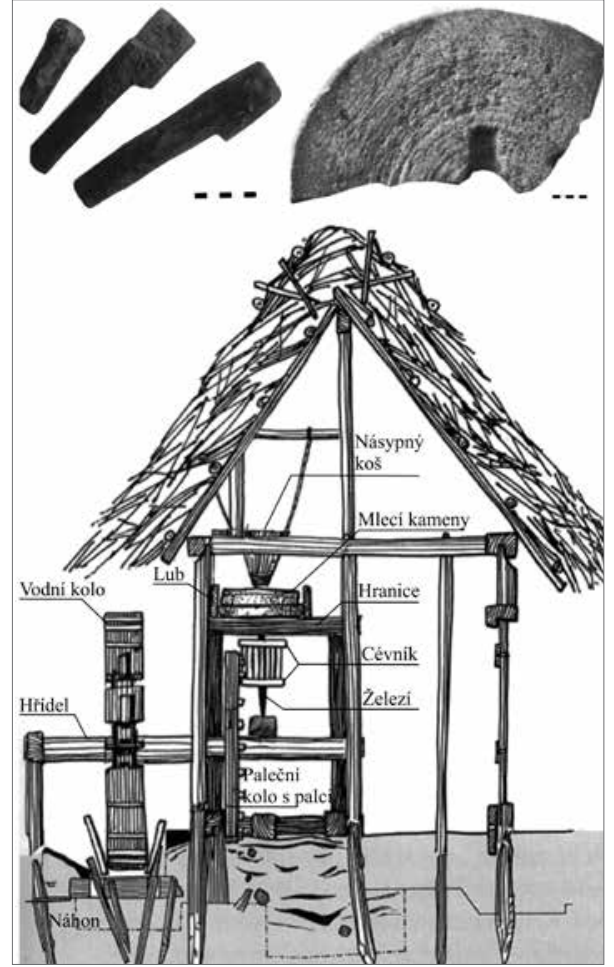

Obr. 8. Dasing, okr. Aichach-Friedberg, Německo. Rekonstrukce vodního mlýna nalezeného při záchranném archeologickém odkryvu v zaniklém korytě řky Paar u bavorského Dasingu. V horní části obrázku výběr zjištěných artefaktủ. Zleva: palce palečního kola, mlecí kámen běhoun z bazaltu. Podle Czysz 1998, 21, 29, 30. Doplnění o informace ke konstrukci mlecího složení L. Galusová.

Abb. 8. Dasing, Landkreis Aichach-Friedberg, Deutschland. Rekonstruktion der in einem Altarm der Paar bei der bayerischen Gemeinde Dasing entdeckten Wassermühle. Im oberen Bildteil eine Auswahl der gefundenen Artefakte. Von links: Kämme (Zähne) des Kammrads (Zahnrads), Läuferstein aus Basaltlava. Nach Czysz 1998, 21, 29, 30. Die Abbildung wurde mit einer Spezifizierung der Konstruktion des Mahlgangs versehen. Ergänzt von L. Galusová. využití drážkové konstrukce. Autor předpokládá, že vodní mlýn měl jedno složení chráněné mlýnskou hranicí, na ní ležely mlecí kameny a nad nimi visel násypný koš (Czysz 1998, 21, 26).

\section{Předpokládaný vodní mlýn u Gredingu (okr. Roth, Bavorsko)}

Záchranný výzkum v blízkosti německého Gredingu (Großhöbing) zjistil v hloubce 2-4 m existenci enormního množství dřevěných pozůstatků vodního mlýna nalézajících se v ploše $14 \times 40 \mathrm{~m}$, které byly dendrochronologicky datovány do 7. až 9. století (Herzig 1998, 254-256). Zařízení bylo založeno na masivních kůlech dlouhých až $2,4 \mathrm{~m}$, které byly zaraženy více než $50 \mathrm{~cm}$ hluboko do údolního štěrku. Stěna byla zbudována patrně na drážku, nejspíše bez tepelné izolace a jako doplňkový materiál se zde pravděpodobně uplatňoval organický výplet. 
V nálezech byly zjištěny početné fragmenty lopatek vertikálního mlýnského kola, zřejmě na spodní vodu, zlomky dřevěných nádob a dřevěných klínů různých velikostí (tamtéž, 248-249). Velké množství organických vzorků bylo získáno též z oblasti hráze, která naznačuje přítomnost rybničního díla. $Z$ druhotného nálezu jediného omletého mlecího kamene lze sice usuzovat na funkci vodního mlýna, avšak sekundární poloha tohoto artefaktu nutí k obezřetnosti (HerzigLiebert-Nadler 1998, 143-146).

\section{Vodní mlýn u Erftstadt-Niederbergu (okr. Rhein-Erft-Kreis, Severní Porýní-Vestfálsko)}

Při záchranném výzkumu v údolí potoka Rot u Erftstadt-Niederbergu byly objeveny pozůstatky vodního mlýna z 9. století. Stavba byla nejspíše roubená a zaujímala plochu $20 \mathrm{~m}^{2}$. Množství nalezených fragmentů vodního kola bylo dostatečné na provedení jeho rekonstrukce, podle které mohlo vertikální vodní kolo na spodní vodu dosahovat průměru $2,3 \mathrm{~m}$. Původní rozměry lopatek patrně dosahovaly $60 \times 30 \mathrm{~cm}$. Mimo pozůstatky vodního kola byl objeven též fragment hř́ídele. Autorka na základě pěti zlomků mlecích kamenů z bazaltu předpokládá, že šlo o obdobný vodní mlýn, jaký byl objeven v údolí řeky Paar u bavorské lokality Dasing (Tutlies 2006, 106-108).

\section{Předpokládaný vodni mlýn v prostoru kláštera Fulda (okr. Fulda, Hesensko)}

Záchranný archeologický odkryv v prostoru kláštera Fulda odhalil fragmenty lopatek z vertikálního vodního kola nejspíše na spodní vodu a zuby z palečního kola (Kind 2007, 380, obr. 6). Ačkoli ve Fuldě v poloze „Langebrückenstraße“ nebyly nalezeny žádné mlecí kameny, T. Kind se domnívá, že dřevěné pozůstatky náleží vodnímu mlýnu fungujícímu v průběhu 9. století (Kind 2007, 379-383).

\section{Vodní mlýn u Bardowicku (okr. Lüneburg, Dolni Sasko)}

Záchranný archeologický odkryv v zaniklém meandru řeky Ilmenau u města Bardowicku odhalil pozůstatky vodního mlýna, datovaného F. Krügerem do 10. až 12. století. Základ stavby tvořily kůly o průměru do $25 \mathrm{~cm}$ a délce od 2,5 do $4 \mathrm{~m}$, které byly zahroceny $\mathrm{v}$ délce až $1 \mathrm{~m}$. Podlaha byla sestavena ze sroubených dubových trámů o průměru $25-35 \mathrm{~cm}$ s fošnami

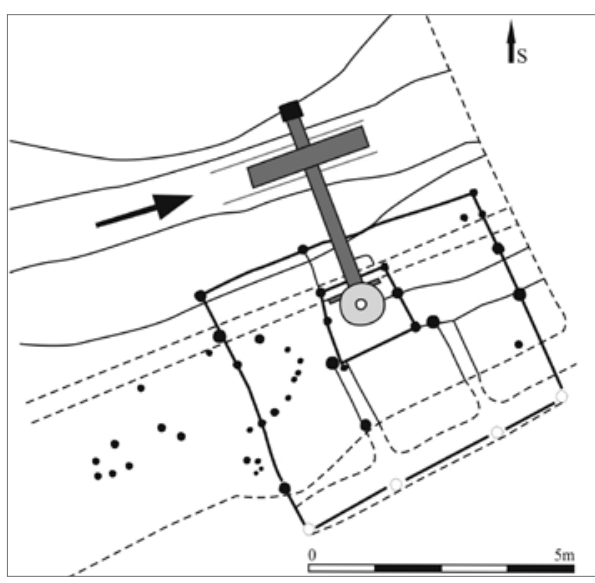

Obr. 9. Grevenbroich, okr. Rhein-Kreis Neuss, Německo. Plán pozůstatků vodního mlýna interpretovaného J. Bertholdem. Relikty byly nalezeny př̀ záchranném archeologickém výzkumu v údolí řeky Elsbach u Elfgenu. Digitalizace L. Galusová podle Berthold 2008, 207.

Abb. 9. Grevenbroich, Rhein-Kreis Neuss, Deutschland. Planskizze der Überreste einer von J. Berthold als solche interpretierten Wassermühle. Die Relikte wurden bei einer im Elsbachtal bei Elfgen durchgeführten archäologischen Rettungsgrabung entdeckt. Digitalisierung L. Galusová nach Berthold 2008, 207. o síle $8-10 \mathrm{~cm}$. Ze stejných trámů byly patrně sroubeny i vlastní stěny objektu (Krüger 1934, 344-345). Při odkryvu byly zjištěny fragmenty vertikálního vodního kola nejspíše na spodní vodu, jehož průměr však nebylo možné kvalifikovaně odhadnout. Zjištěný náhon měřil přibližně $250 \mathrm{~m}$ a $\mathrm{v}$ jeho blízkosti se nalézaly i fragmenty dřevěného stavidla, kterým bylo ovládáno množství vody vedoucí ke mlýnu. Při výzkumu byly získány mlecí kameny o průměru $70-90 \mathrm{~cm}$ a současně též fragment cévníku. Cévník o síle $5-6 \mathrm{~cm}$ dosahoval průměru $29 \mathrm{~cm}$ a byl opatřen šesti otvory pro zasazení cév o průměru $3,5 \mathrm{~cm}$ a středovým otvorem o průměru $6,5 \mathrm{~cm}$, kterým procházelo železí, snad usazené do kuželice (tamtéž, 348).

Vodní mlýn u Grevenbroichu [Elfgen] (okr. Rhein-Kreis Neuss, SeverníPorýni-Vestfálsko)

Při záchranném archeologickém výzkumu v údolí řeky Elsbach u Elfgenu byly 


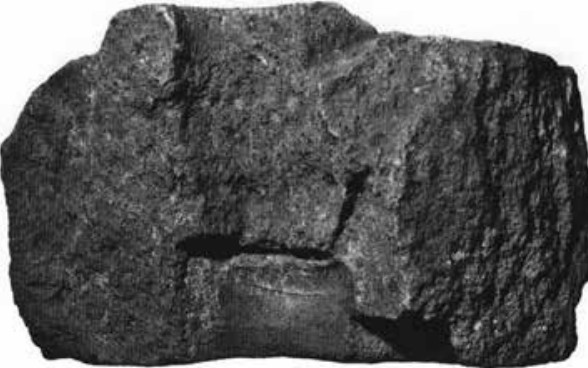

Obr. 10. Grevenbroich, okr. Rhein-Kreis Neuss, Německo. Fragment mlecího kamene běhounu zjištěného v údolí řeky Elsbach u Elfgenu. V oku běhounu jsou pozorovatelné stopy opotřebování mlecího kamene. Podle Berthold 2008, 228, Taf. 1.

Abb. 10. Grevenbroich, Rhein-Kreis Neuss, Deutschland. Im Elsbachtal bei Elfgen gefundenes Läufersteinfragment. Im Mühlauge des Läufersteins sind Abnutzungsspuren erkennbar Nach Berthold 2008, 228, Taf. 1.

objeveny pozůstatky vodního mlýna z 11 . až 13. století nejspíše s vertikálním kolem na spodní vodu a náhonem. Objekt mlýna byl celodřevěný s piloty, které držely platformu o velikosti $42 \mathrm{~m}^{2}$, na níž stála stavba mlýna (obr. 9). Průměr kola byl odhadnut $\mathrm{v}$ důsledku znalosti původního terénu minimálně na $3 \mathrm{~m}$. V blízkosti stavby bylo objeveno velké množství úlomků mlecích kamenů z bazaltu s vsekaným otvorem pro dvouramennou kypřici (obr. 10). Mimo dřevěných pozůstatků a mlecích kamenů byl objeven nástroj na ostření mlecích kamenů, zvaný oškrt (Berthold 2008, 179-215).

\section{Předpokládaný vodni mlýn u Jüterbogu (okr. Teltow-Fläming, Braniborsko)}

Záchranný archeologický výzkum v blízkosti města Jüterbog přinesl objev pozůstatků vodního mlýna nejspíše s vertikálním kolem na spodní vodu, který se nalézal pod jezovým dřevo-hlinitým dílem, od něhož vedl k vodnímu mlýnu krátký vydřevený náhon z druhé poloviny 12. století. $Z$ archeologického výzkumu vyplývá, že náhon byl zřejmě vybaven vršemi (zařízení k lovu ryb). Jednotlivé konstrukční prvky byly spojeny plátováním a čepováním, současně se pravděpodobně uplatňovala technika na drážku a jako doplňkový prvek sloužil organický výplet. Vznik mlýna a jeho zázemí je dáván do souvislosti se vznikem a působením blízkého cisterciáckého kláštera Zinna (Schwarzländer 2003, 143-145).

\section{Vodní mlýn u obce Ahrensfelde (okr. Barnim, Braniborsko)}

Při záchranném archeologickém výzkumu v Ahrensfelde byl odkryt vodní mlýn, který $\mathrm{v}$ této poloze pracoval od počátku 14. do konce 16. století. Na sklonku uvedené epochy mlýn do základů vyhořel a již nebyl obnoven (Kellermann 1953, 67). Mlýnská stavba byla vybavena vertikálním kolem o průměru $4,5 \mathrm{~m}$. Dle zjištěného spádu $0,60-0,70 \mathrm{~m}$ šlo nejspíše o kolo na spodní vodu napájené korytem z jednoho kusu kmene o rozměrech $4,75 \times 0,60 \times 0,60 \mathrm{~m}$. Kromě pozůstatků vodního kola byl objeven fragment hř́dele o průměru $0,45 \mathrm{~m}$, při okraji pouze $0,30 \mathrm{~m}$. Užší část byla patrně uložena v dřevěném ložisku, které spočívalo na odhalených dřevěných podpěrách (Issleib 1953, 68-70). Mlýnská stavba rámové konstrukce se rozkládala na ploše $34 \mathrm{~m}^{2}$, členěná do tří prostor. Severní část zaujímala vlastní mlýnice v ploše $13 \mathrm{~m}^{2}$, v jejímž nitru byl objeven mlecí kámen z bazaltu o průměru $1,2 \mathrm{~m}$. Za touto částí se nalézala síň. Poslední místnost obrácená k jihu byla vybavena dřevěnou podlahou. Zřjejmě sloužila jako příruční sklad. V tomto prŕípadě šlo patrně o jednoduchou místnost beze stěn, s kủly v rozích (Kellermann 1953, 66). Vodní kolo dle všech indicií mělo nejspíše výkonnost maximálně 5 a minimálně 3 koňské síly (Issleib 1953, 68-70). Šlo tedy o běžný malý venkovský technický objekt, v jehož nitru se slučovaly obytná, technická a provozní funkce. Bohužel není zřejmé, zda uvedená dispozice mlýnské stavby je výsledkem pozdějších transformací v průběhu 16. století, či zda byl mlýn takto vybaven již při svém založení. Na lokalitě byly nalezeny velké trámy o průměru 0,25 až $0,35 \mathrm{~m}$, které byly součástí jak samotné stavby, tak i rybniční hráze. Pozůstatky rybničního díla se skládaly z roubené komory ze silných dubových trámů a rámové konstrukce. V hrázi byly objeveny též dřevěné pozůstatky stavidla (Kellermann 1953, 64-67).

\subsection{Rakousko}

\section{Předpokládaný vodní mlýn u Rabensburgu (okr. Mistelbach, Dolni Rakousko)}

Záchranný archeologický výzkum objevil na území Rakouska u Rabensburgu pozůstatky vodního mlýna ze 13.-15. století, který ležel u zaniklého koryta vedlejšího přítoku Dunaje. 


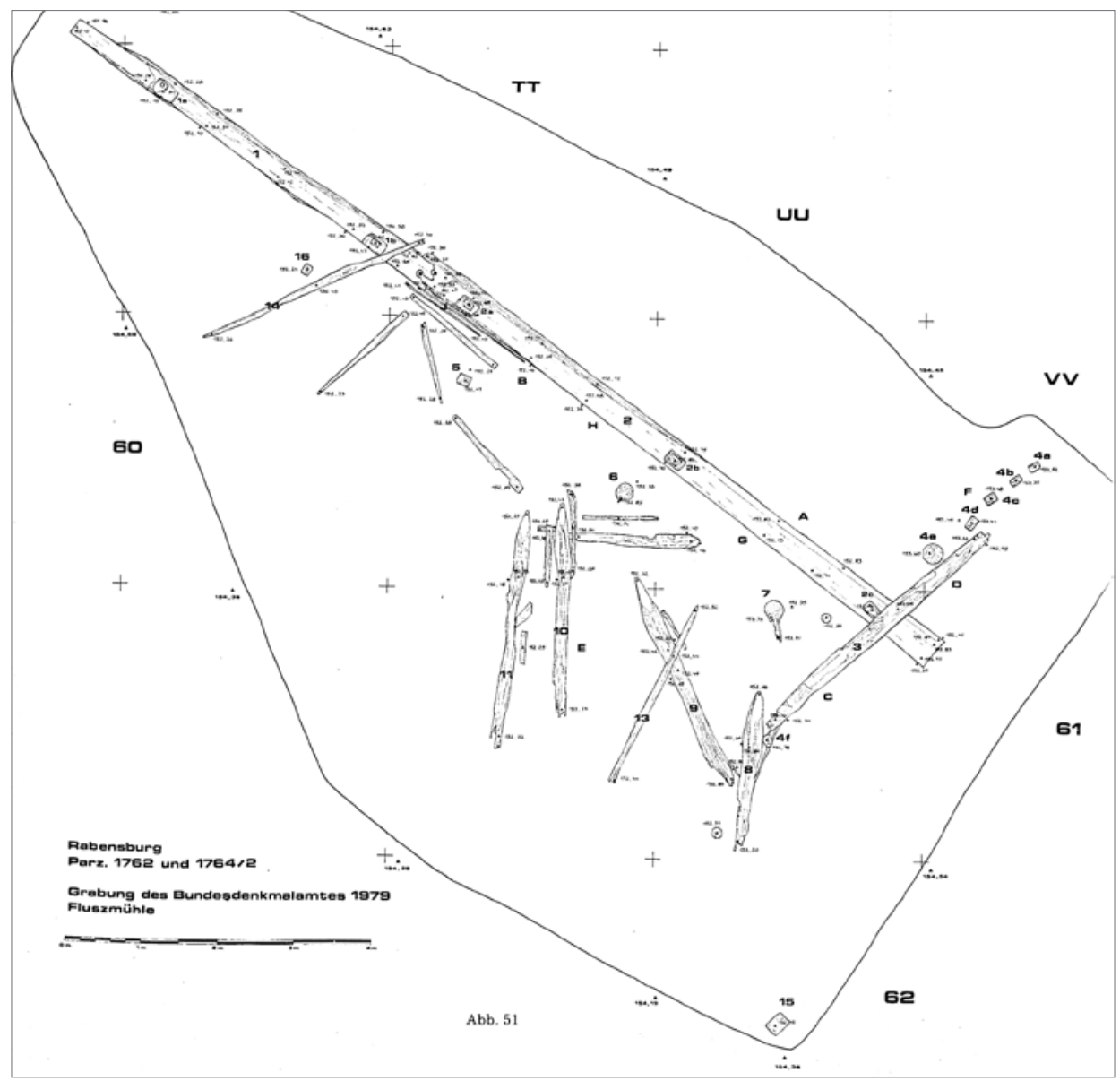

Obr. 11. Rabensburg, okr. Mistelbach, Rakousko. Plán dřevěných pozůstatkủ předpokládaného vodního mlýna odhaleného při záchranném archeologickém odkryvu v zaniklém korytě př́toku řeky Dunaje. Podle Adler-Hundbichler 1980, Abb. 51.

Abb. 11. Rabensburg, Bezirk Mistelbach, Österreich. Planskizze der hölzernen Überreste einer durch eine in einem verlandeten Nebenarm eines Donauzuflusses durchgeführte archäologische Rettungsgrabung freigelegten mutmaßlichen Wassermühle. Nach Adler-Hundbichler 1980, Abb. 51.

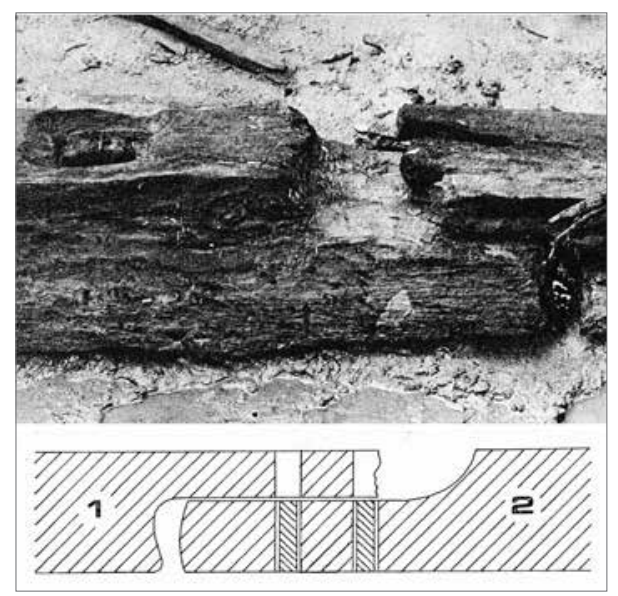

Poloha mlýna byla dána několika dřevěnými trámy o délce přibližně $6 \mathrm{~m} \mathrm{~s}$ různými průřezy od $0,2 \times 0,17$ až do $0,30 \times 0,20-0,25 \mathrm{~m}$. Současně byly zjištěny do země zapuštěné kůly o celkové délce $2,5 \mathrm{~m}$. V prostoru lokality se dále nalézaly dřevěné kolíky o rozměrech $0,11 \times 0,07 \mathrm{~m}$, které sloužily pro zajištění trámů do konstrukcí. Vyjma těchto artefaktů byly zjištěny fragmenty sloupů a různých fošen i prken (obr. 11). Na lokalitě byla uplatněna jako hlavní stavební technika vzájemná vazba

Obr. 12. Rabensburg, okr. Mistelbach, Rakousko. Spojovací technika trámů 1 a 2. Měř́tko kresby 1:10. Podle Adler-Hundbichler 1980, 17-18.

Abb. 12. Rabensburg, Bezirk Mistelbach, Österreich. Die Verbindungstechnik zwischen Balken 1 und 2. Darstellung im Maßstab 1:10. Nach Adler-Hundbichler 1980, 17-18. 
hraněných konstrukčních prvků plátováním a čepováním (obr. 12). Velikost ani počet kol nelze dle nálezové situace stanovit. Mlecí kámen nebyl objeven, avšak na základě písemných pramenů se v tomto prostoru předpokládá existence vodního mlýna (Adler-Hundsbichler 1980, 9-54).

\subsection{Polsko}

Polské výzkumy jsou pro české podmínky významnými analogiemi. Zvodnělé prostředí zde tak jako v jiných částech Evropy uchovalo mnohé dřevěné konstrukce, které významně přispívají k pochopení vybavení středověkého vodního mlýna.

\section{Vodni mlýn u Otołąžky (okr. Grójec, Mazovské vojvodství)}

Záchranný archeologický výzkum v blízkosti obce Otołąžka u řeky Mogielanka odhalil pozůstatky vodního mlýna datované do konce 13. až průběhu 15 . století. Dle polohy reliktů lze soudit, že šlo o mlýn s vertikálním kolem na spodní vodu, avšak pozůstatky kola nebyly nalezeny. Významným zjištěním byly $\mathrm{v}$ této poloze fragmenty mlecích kamenů $\mathrm{z}$ pískovce o průměru $70 \mathrm{~cm}$, základy stavby založené na pilotech s hrubou platformou a pozůstatky dřevěného náhonu (Bender 1974, 213-230).

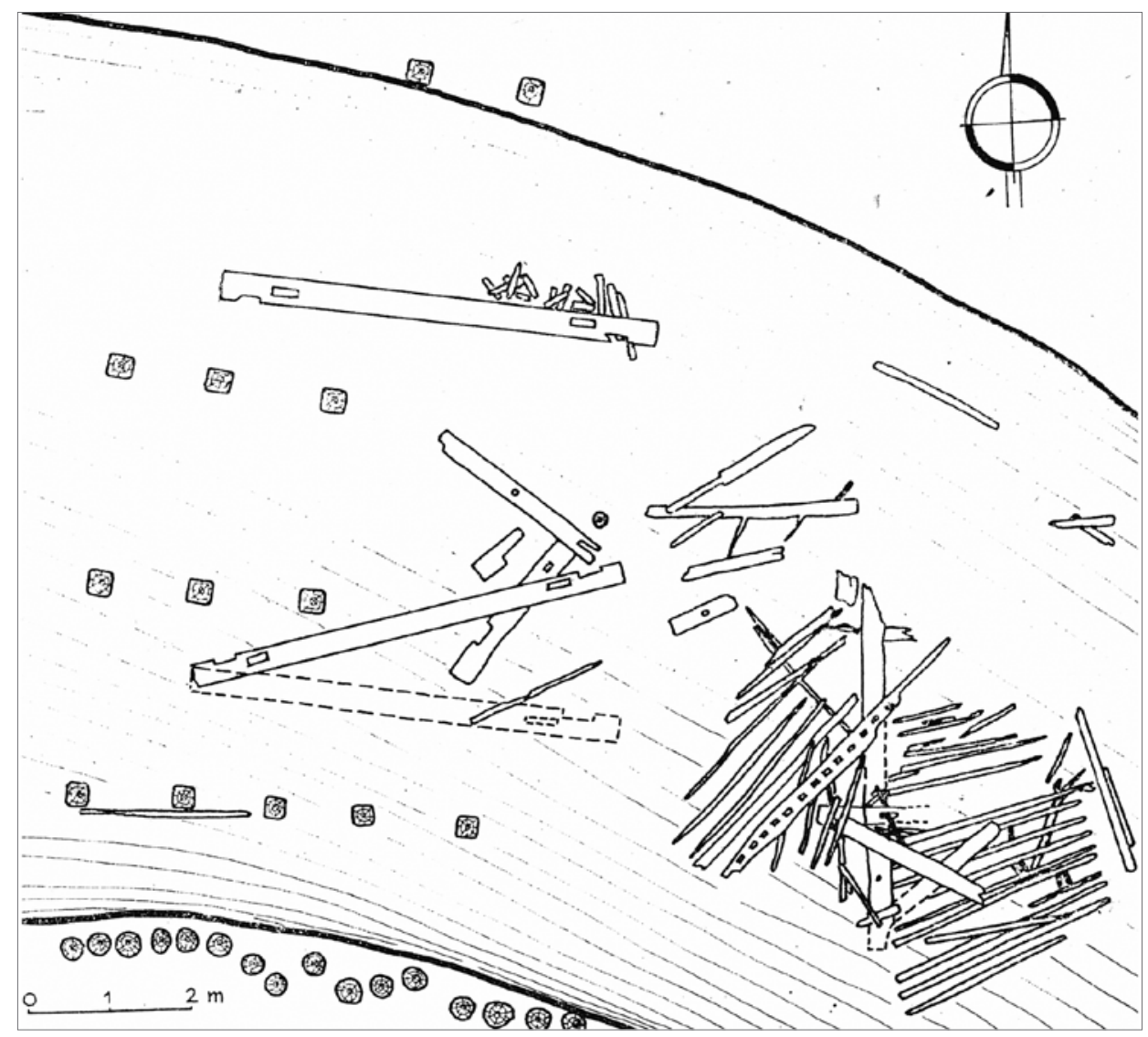

Obr. 13. Ptakowice, okr. Tarnowskie Góry, Polsko. Plán reliktů interpretovaných jako pozůstatky vodního mlýna, který byl zjištěn při záchranném archeologickém odkryvu v zaniklém rameni koryta Ptakovického potoka - př́ítoku Kladské Nisy. Podle BagniewskiKubów 1977, 15.

Abb. 13. Ptakowice, Landkreis Tarnogórski, Polen. Planskizze der als Überreste einer Wassermühle interpretierten Relikte, die bei einer archäologischen Rettungsgrabung in einem verlandeten Arm des Baches von Ptakowice, einem Zufluss der Glatzer Neisse, gefunden wurde. Nach Bagniewski-Kubów 1977, 15. 


\section{Předpokládaný vodní mlýn u Ptakowic (okr. Tarnowskie Góry, Slezské vojvodství)}

Při záchranném archeologickém výzkumu byly $2 \mathrm{~m}$ pod povrchem odkryty relikty vodního mlýna v zaniklém rameni koryta Ptakovického potoka, př́itoku Kladské Nisy (Kłodzka Nysa). Byl zde objeven systém 15 dubových kůlů o celkové délce 2,35-2,55 m a několika hraněných trámů o shodném průřezu $0,3 \mathrm{~m}$, které vymezovaly platformu o rozměrech $7,5 \times 3,5 \mathrm{~m}$, na které stál mlýn (obr. 13). Současně byly zjištěny pozůstatky mostku a fragment patrně hrázděné stěny domu. Hlavními stavebními technikami zde byly plátování a čepování jednotlivých opracovaných trámů a dalších konstrukčních prvků, které tvořily základy stavby, stěny byly tvořeny formou hrázděné konstrukce. Významným nálezem vyjma vlastní mlýnské stavby je též otisk železí, nalézající se na dřevěném sloupu o průměru $10 \mathrm{~cm}$ (Bagniewski-Kubów 1977, 13). Dále byly zjištěny zlomky vyhlazených prkýnek, které snad mohly být součástí násypného koše, jenž zajištoval sypání obilí do oka běhounu (tamtéž, 28). Je s podivem, že na lokalitě nebyly zachovány fragmenty mlecích kamenů a současně také téměř žádné kovové předměty (na místě je tedy otázka, zda zjištěný mechanismus byl skutečně vodním mlýnem). Autoři výzkumu spekulují, že tyto pozůstatky byly odneseny vodním živlem mimo zkoumanou plochu, případně železné artefakty plně zkorodovaly a zanikly, či byly odneseny před zánikem stavby do nového mlýna. Nálezy byly datovány do druhé poloviny 13 . století až první poloviny 15 . století, kdy mlýn zanik1 požárem. Z archeologických situací je zřejmé, že mlýn byl v průběhu 14. století modernizován. Dle rekonstrukce mohl být tedy objekt vybaven dvěma vertikálními koly na spodní vodu o průměru 1,5-2 m (tamtéž, 3-33).

\section{Vodni mlýn u obce Dragacz (okr. Świecie, Kujavsko-pomořské vojvodství)}

V souvislosti s polským záchranným výzkumem v blízkosti koryta Staré Matawy byly v Mniszku u obce Dragacz odhaleny dřevěné konstrukční prvky vodního mlýna s příslušenstvím a fragmenty kovů i keramiky, jejichž datace sahá od pozdního středověku do novověku. Celkem bylo získáno více než 200 dřevěných prvků. Zvláštní pozornost si zaslouží 75 kusů horizontálně uložených dubových zašpičatělých kůlů a fragmenty vbitých borových lišt i vertikálně uložených latí, které tvořily základy platformy jak vlastního mlýna o rozměrech $5 \times 10 \mathrm{~m}$, tak další budovy v blízkosti mlýnského objektu (snad př́ibytku mlynáře). Jednotlivé konstrukční prvky byly spojeny plátováním a čepováním, současně zde byla rozpoznána technika na drážku, aplikovaná na stěny domu. Vyjma těchto konstrukcí byly zjištěny fragmenty dřevěného žlabu o délce 14,5 a výšce $0,5 \mathrm{~m}$, interpretovaného jako vantroky, a pozůstatky 44 fragmentů vodního kola, na jejichž základě bylo možné rekonstruovat jeho průměr, který činil více než tři metry o celkové šíři 1,2 m. Dle tvarů pozůstatků tohoto artefaktu je velmi pravděpodobné, že jde o vertikální kolo na horní vodu. V jeho blízkosti byl relativně dobře dochován pozůstatek vantrokového žlabu s ochrannou výpustí o délce $10 \mathrm{~m}$ s profilací ve tvaru „V“ $\mathrm{V}$ podélném řezu a také dvě konstrukce, každá na jedné straně lednice, které nesly ložiska hř́idele. Západní podpůrná konstrukce dosahovala rozměru $104 \times 230 \mathrm{~cm}$ a východní konstrukce se rozkládala na ploše $180 \times 395 \mathrm{~cm}$, přičemž jejich výška se pohybovala od 1,3 až do $1,7 \mathrm{~m}$ (Górzyńska-GórzyńskiMajewski 2011, 61, 65). Mimo těchto pozůstatků byl na stanovišti lokalizován rybník se zbytky hráze zbudované z borovicových latí a hlinito-kamenité konstrukce (obr. 14). Při rekonstrukci objektu se uplatnila kombinace výsledků archeologického výzkumu a etnografických poznatků (tamtéž, 63).

Funkce mlýna z Mniszku byla potvrzena jak písemnými prameny, tak archeologickým nálezem, jelikož byly objeveny dvě části silně omletého mlecího kamene z pískovce, patrně ležáku, o průměru přibližně $80 \mathrm{~cm}$ a tloušt'ce $4,5 \mathrm{~cm}$ (tamtéž, 66). Odpověd' na otázku, proč v průběhu novověku mlýn zanikl, však archeologický výzkum nepodal. Na základě prvních dendrochronologických výsledků bylo zjištěno, že dřeviny, z nichž jsou zbudovány piloty platformy mlýna, byly smýceny kolem roku 1380, a dřeva tvořící „dlažbu“ náhonu ještě o 20 let dříve. Klíčová je datace věnce kola do období 1421/1422 (tamtéž, 67). 


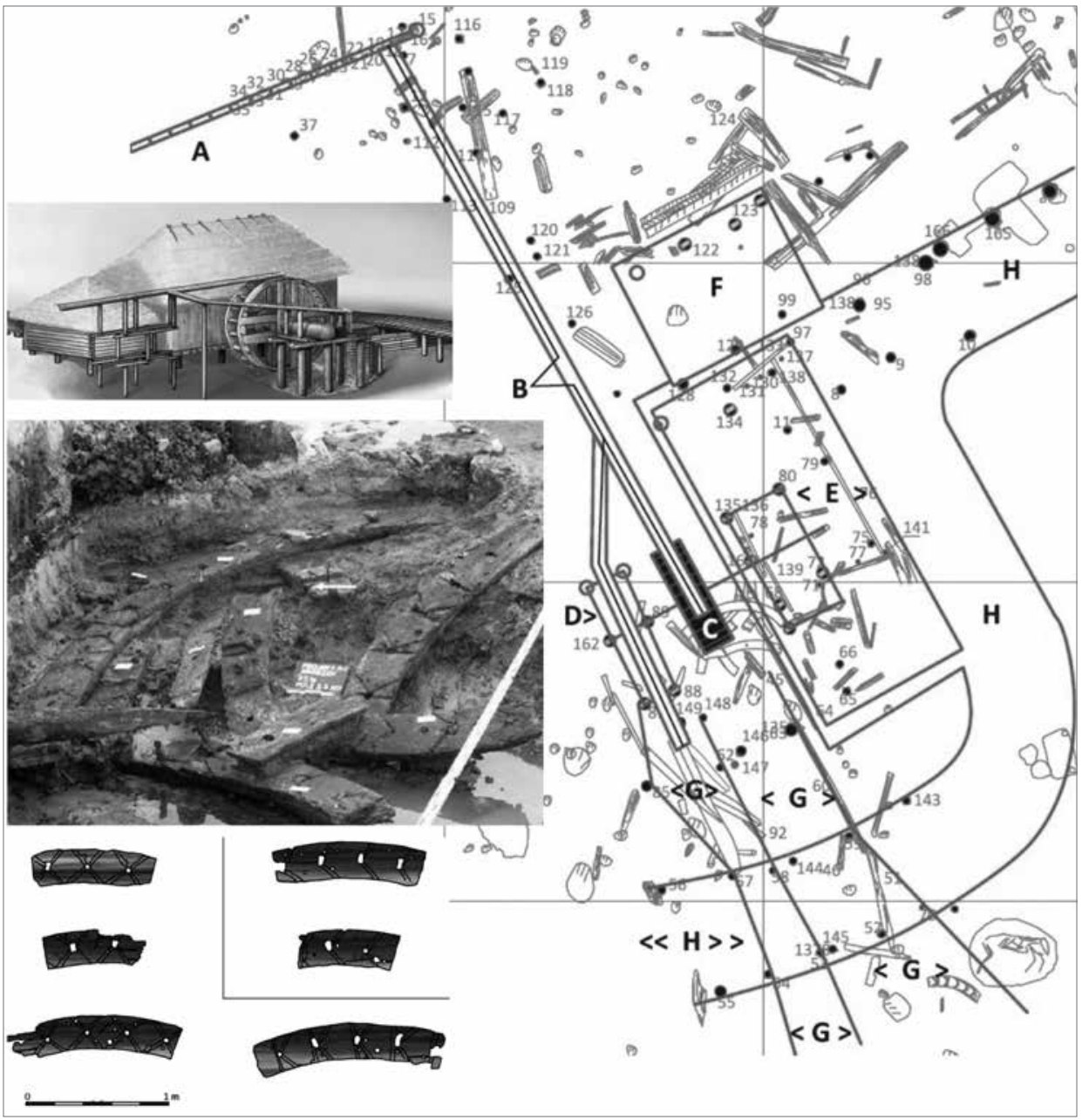

Obr. 14. Dragacz, okr. Świecie, Polsko. Plán, fotografie, kresba a model zaniklého vodního mlýna nalezeného při záchranném archeologickém výzkumu. Zachování dřevěných reliktů zde bylo mimořádné. Pozoruhodným prvkem jsou věnce vodního kola, které byly patrně součástí korečníku s korečky ve tvaru písmene „V“v podélném řezu. A - propust', B - vantroky, C - věnce vodního kola, D - západní podpora vodního kola, $E$ - východní podpora vodního kola, $F$ - založení platformy budovy mlynáře či hospodářské budovy, $G$ - odpadní koryto, H - původní koryto Staré Matawy. Podle Górzyńska-Górzyński-Majewski 2011, 61-62, 64, 66.

Abb. 14. Dragacz, Landkreis Świecki, Polen. Planskizze, Fotographie, Zeichnung und Modell einer ehemaligen Wassermühle, die in einer archäologischen Rettungsgrabung entdeckt wurde. Bemerkenswertes Element sind die Kränze des Wasserrads, die offenbar Bestandteil eines Zellenrades mit im Längenprofil V-förmigen Zellen waren. A - Durchlass, B - Wandtrog, C - Wasserradkränze, D - westliche Stütze des Wasserrads, E - östliche Stütze des Wasserrads, F - Gründung des Mühlen- oder Wirtschaftsgebäudes in Form einer Plattform, G - Abflussgerinne, H - ursprüngliches Gerinne Stará Matawa. Nach Górzyńska-Górzyński-Majewski 2011, $61-62,64,66$.

\section{Podoba a vybavení středověkého vodního mlýna}

Na základě publikovaných faktů (tab. 1) a výše jmenovaných výzkumů se lze domnívat, že nejpozději od raného středověku byly vodní mlýny ve sledovaných zemích vybaveny obdobnými typy zařízení, která vykazují podobné formální vlastnosti (kupříkladu vzhled palců palečního kola, velikost a podoba cévníku, vzhled vsekaných otvorů pro kypřici v běhounech). Př́liš velký prostor pro srovnávání však nemáme, protože počet nálezů artefaktů je minimální. Současně je třeba podotknout, že některé předpokládané artefakty nebyly doposud v archeologických nálezech zjištěny (násypný koš, lub, čepy a zděře hřídele aj.). Mimo tyto problémy je nutné upozor- 


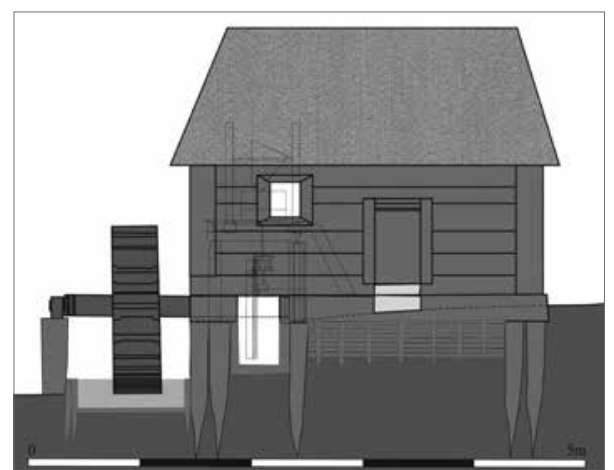

Obr. 15. Hypotetický model středověkého vodního mlýna pro oblasti se zvodnělými sedimenty v okolí řek. Jde o vodní obilný mlýn s vertikálním vodním kolem - lopatníkem na spodní vodu a obyčejným mlecím složením bez mechanického prosévání a bez lubu. Konstrukce objektu drážková, bez tepelné izolace. Autorka L. Galusová.

Abb. 15. Hypothetisches Modell einer mittelalterlichen Wassermühle für Gebiete mit Grundwassersedimenten in der Umgebung von Flüssen. Es handelt sich um eine Getreidewassermühle mit vertikalem, unterschlächtigem Schaufelrad und gewöhnlichem Mahlgang ohne mechanisches Sieben und ohne Zarge (Bütte). Bauweise des Objekts Nut- und Federkonstruktion, ohne Wärmeisolierung. Erstellt von L. Galusová.

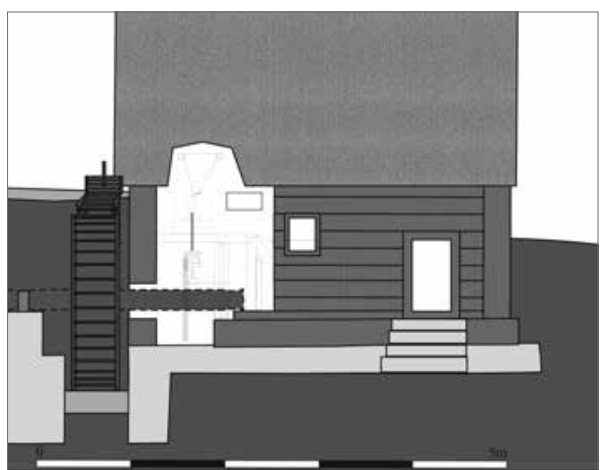

Obr. 16. Hypotetický model středověkého vodního mlýna pro oblasti s pevným podložím. Jde o vodní obilný mlýn s vertikálním vodním kolem - korečníkem na horní vodu a obyčejným mlecím složením bez mechanického prosévání a bez lubu. Konstrukce objektu drážková, bez tepelné izolace. Autorka L. Galusová.

Abb. 16. Hypothetisches Modell einer mittelalterlichen Wassermühle für Gebiete mit festem Untergrund. Es handelt sich um eine Getreidewassermühle mit vertikalem, oberschlächtigem Zellenrad und gewöhnlichem Mahlgang ohne mechanisches Sieben und ohne Zarge (Bütte). Bauweise des Objekts Nutund Federkonstruktion, ohne Wärmeisolierung. Erstellt von L. Galusová.

nit na skutečnost, že archeologické rekonstrukce raně až pozdně stř̌edověkých vodních mlýnů, představených na konferenci v Lon-le-Saunier v roce 2011, byly P. Millem vyhodnoceny jako nedostatečně funkční, vyjma rekonstrukce vodního mlýna v Dasingu (Mille 2011, on-line). To může znamenat, že na lokalitách se v průběhu času vyskytlo více jednotlivých vodních mlýnů, které byly $\mathrm{v}$ rámci rekonstrukce nevhodně sestaveny, případně došlo $\mathrm{k}$ chybě $\mathrm{v}$ rekonstrukci vodního kola či byly vodní mlýny vystrojeny odlišně, než jak je zpracovali autoři výzkumů.

\subsection{Založení vodního mlýna}

Vodní mlýn v prostředí zvýšené spodní hladiny byl založen na platformě fixované piloty a s konstrukcí trámů pojených plátováním na rybinu a čepováním. Povrch platformy sestával z fošen, začepovaných do trámů malými kolíky o délce přibližně $10 \mathrm{~cm}$ a průměru $2-5 \mathrm{~cm}$. Plocha těchto platforem se ve vrcholném a pozdním středověku nejčastěji pohybovala mezi 25 až $35 \mathrm{~m}^{2}$ (Kellermann 1953, 66; Berthold 2008, 212), jsou však známy i prŕípady ploch o $50 \mathrm{~m}^{2}$ (Górzyńska-Górzyński-Majewski 2011, 66; Kudrnáč-Huml 1969, 37; obr. 15). Pokud mlýn stál na pevném podloží, byl umístěn nejspíše na kamenné podezdívce, případně na lehkém kamenném základu (Kašpar-Smejtek-Vařeka 1999, 104-105; Galusová 2014, 90; obr. 16).

\subsection{Stavba vodního mlýna}

Stěny mlýnského objektu mohly být roubeny na rybinu (Górzyńska-Górzyński-Majewski 2011, 66), zbudovány jako konstrukce na drážku (Schwarzländer 2003, 143-145; Czysz 1998, 22-23) či sestávaly z roubené konstrukce (Kašpar-Smejtek-Vařeka 1999, 105), prŕípadně z nepálených cihel (Durdík 2001, 28). Objekt však mohl být zbudován též jako stavba z kamenného zdiva (Richterová 1987, 183-188), výjimečně snad jako celokamenný.

Dle archeologického výzkumu mlýnice zaujímala plochu minimálně 6-9 $\mathrm{m}^{2}$ a maximálně snad kolem 20 m² (Czysz 1998, 16). Úroveň mlecí podlahy, kde bylo nasýpáno obilí do mlecího stroje, byla dána svrchní rovinou hranice. Do tohoto prostoru se vstupovalo pravděpodobně po dřevěných schodech (Kellermann 1953, 68-69). 
Středověké vodní mlýny byly nejspíše vybaveny sedlovou či valbovou střechou s jednoduchým krovem (Czysz 1998, 20-21). Krytinu pak tvořil patrně došek (Czysz 1998, 21) nebo šindel (Bagniewski-Kubów 1977, 26), výjimečně pálená krytina (Kašpar-Smejtek-Vařeka 1999, 106). Dále lze předpokládat existenci oken a dveř́i. Tyto skutečnosti však nebyly archeologickým průzkumem doposud potvrzeny. Otázku podoby a umístění okenních a dveřních otvorů je možné řešit pomocí ikonografie. Na základě ikonografických zobrazení lze předpokládat jeden až tři malé okenní otvory, nejčastěji pravoúhlé, obdélné, př́ípadně snad zaklenuté, a to ve štítové i okapové stěně, a dále jeden dveřní otvor pravoúhlý či zaklenutý též ve štítové či okapové stěně. Otázka podoby vlastních dveří je problematická, jelikož na vyobrazeních ve většině prrípadů scházejí. Lze předpokládat jejich otevření dovnitř budovy nebo jejich úplnou absenci (Pfau 1967, fol. 84r; Štěpán-Urbánek-Klimešová 2008, 14, obr. 22).

Nejpozději od pozdního středověku snad mohly být mlýnice spojovány s obytnou i skladovací funkcí, a tvořily tak trojdílné či vícedílné objekty pod jednou střechou. Tato skutečnost je však jednoznačně doložena pouze u mlýnského objektu odkrytého v brandenburském Ahrensfelde, který zanikl až ve druhé polovině 16. století, a toto funkční propojení tak může souviset až s mladšími úpravami v raném novověku. Současně je ovšem třeba poznamenat, že některé objekty z vrcholného či pozdního středověku obsahují situace, na jejichž základě by bylo možné se domnívat, že šlo o vícedílný objekt (Bagniewski-Kubów 1977, 13; Berthold 2008, 207).

\subsection{Výstroj vodniho mlýna}

Za současného stavu archeologického poznání mohly být nastíněné konstrukční varianty venkovských středověkých vodních mlýnů nejspíše vybaveny vodním kolem o průměru nepřesahujícím $4 \mathrm{~m}$, přičemž paleční kolo dosahovalo přibližně dvou třetin velikosti kola vodního (Górzyńska-Górzyński-Majewski 2011, 66; Czysz 1998, 21), případně snad mohlo být i menší. S téměř naprostou převahou šlo o vodní kola na spodní vodu, vyjma pozdně středověkého vodního mlýna odkrytého u obce Dragacz v Polsku (Górzyńska-Górzyński-Majewski 2011, 59-68). Výsledné zjištění převahy mlýnů s koly na spodní vodu však může být pouze zdánlivé, zapř́íčiněné tím, že většina objektů byla odkryta v nížinných polohách v prostředí větších řek, kde pracovaly mlýny s koly na spodní vodu (např. v Čechách Písek, v Německu Gimbsheim, Dasing, Erftstadt-Niederberg, Bardowick, Jüterbog, v Rakousku Rabensburg). Lokality, které byly odkryty mimo takovéto prostředí, neobsahují organické pozůstatky (v Čechách a na Moravě Vyžlovka ve Spáleném, Libkovice, Ústupenice, Mstěnice, v Německu Lösnich). Jde často o objekty zjištěné ve vyšších nadmořských polohách či oblastech s nižší vodnatostí. V takovýchto situacích je takřka nemožné interpretovat zaniklou technologii, což zajisté výsledný poměr mlýnů s koly na horní a spodní vodu zkresluje. Současně - v souvislosti s evolucionistickým principem - existuje domněnka, že ve vrcholném středověku bylo etablování kola na horní vodu (jakožto konstrukčně složitějšího vodního motoru) postupné, přičemž z méně vodnatých poloh vytlačovalo kolo na spodní vodu, které v těchto podmínkách pracovalo s nižší účinností. Možnou existencí vodních kol na spodní vodu ve vyšších nadmořských polohách a etablováním kol na horní vodu se v minulosti zabýval Luděk Štěpán (např. Štěpán 2000, 55; 2012, 14-19). Archeologie za současného stavu poznání však tuto problematiku není schopna vyjasnit.

Zmíněné vodní kolo společně s palečním kolem bylo začepováno do vodorovné dřevěné hř́idele, která byla zajisté uložena do dvou ložisek. Materiál ložisek, stejně jako kovaných čepů, známých z raně novověkých mlýnů, nebyl při archeologickém výzkumu doposud zjištěn. Průměr hlavní hřídele se v závislosti na velikosti kol nejspíše pohyboval kolem $40 \mathrm{~cm}$ (Kellermann 1953, 69). Dle upevnění věnce vodního kola k hřídeli se konstrukce kola označuje bud' jako konstrukce na dlab, nebo jako obkročák (Petráň 1985, 393; Dvořáková-Merta 2005, 115). Ve středověku lze předpokládat spíše jednodušší konstrukci na dlab (Kellermann 1953, 64, Tafel XXIV; Dvořáková-Merta 2005, 119, obr. 5), avšak minimální archeologické nálezy hřídelí vodních kol tuto hypotézu jednoznačně nedokládají. Vyjma hřídele vodního kola byla výjimečně zazname- 
nána též konstrukce, na níž byla hřídel vodního kola usazena (Górzyńska-Górzyński-Majewski 2011, 65). Z převodového mechanismu byly na sledovaném území archeologicky zjištěny též dvě céví, pozůstatek železí a palce palečního kola. Cévník o průměru $25-30 \mathrm{~cm}$ se šesti cévy (Krüger 1934, 348) pevně obepínal železí (Höckmann 1994, 207) a zapadal do palců palečního kola (Czysz 1988, 21). Železí bylo ukotveno v ložisku v podkolí na trámu či kůlu, na takzvané kobylici (Bagniewski-Kubów 1977, 13), a následně procházelo mlecí podlahou i ležákem opatřeným kuželicí, která jej vystředila (Berthold 2008, 211). Kuželice však byla doposud interpretována pouze $\mathrm{u}$ raně středověkého vodního mlýna $\mathrm{v}$ severoirské lokalitě Nendrum (Manning 2007, 165-167). Železí dále neslo kypřici, nejspíše kovovou, jejíž dva jediné exempláře uvádějí W. Gaitzsch-B. Päffgen (1995, 256) a J. Berthold (2008, 211). Na kypřici nasedal běhoun (Czysz 1998, 30, Berthold 2008, Tafel 1). Na základě pozůstatků otvorů vsekaných do spodní části mlecího kamene běhounu, pocházejícího $\mathrm{z}$ vrcholně stř̌edověké lokality Elfgen, Jens Berthold předpokládá velikost kypřice minimálně $24 \times 6 \times 3,5 \mathrm{~cm}$ a průměr oka ve středu mlecího kamene odhaduje kolem $15 \mathrm{~cm}$ (Berthold 2008, 196-197). Takovéto kypřice mohly být běžné v období vrcholného až pozdního středověku.

Rozpohybování železí (pomocí palečního kola a cévníku) uvedlo do pohybu mlecí kámen běhoun, který se otáčel v určité vzdálenosti od stabilního mlecího kamene - ležáku. Průměr mlecích kamenů se v našich podmínkách pohyboval kolem $70 \mathrm{~cm}$. Analogie $\mathrm{k}$ nim lze spatřovat v polských mlecích kamenech (viz tab. 1). U píseckého rudného mlýna můžeme předpokládat, že byl vybaven větším mlecím kamenem, než jaké se běžně užívaly do vodních mlýnů, jelikož byl určen k jinému účelu. Předpokládá se znalost lehčení běhounu (Suppan 1995, 108), jeho technické řešení však prozatím nebylo archeologickými výzkumy uspokojivě doloženo. Mezi těmito mlecími kameny opatřenými křesem (Berthold 2008, 202; Jaccottey-Farget 2011, 51-68; Štěpán 2012, 16-17) se posléze rozemílalo obilí na melivo, které se následně třídilo vyséváním na různé produkty. Nejprve ručně, pomocí sít, a nejdříve na sklonku středověku i mechanicky. Mlýnská hranice, která byla doložena archeologickým výzkumem spíše výjimečně (Czysz 1998, 26), chránila převody mlýna a nesla mlecí podlahu z dřevěných fošen, na níž se nacházel mlecí kámen ležák, nad nímž byl umístěn mlecí kámen běhoun, nasazený na kypřici. Nad běhounem lze logicky předpokládat násypný koš (viz obr. 8). Jeho jednoznačný doklad v archeologickém materiálu však prozatím schází.

$\mathrm{K}$ vodnímu mlýnu byla voda nejčastěji přiváděna vodním náhonem z rybníka či jezového díla, který byl opatřen stavidlem (viz tab. 1). Pokud šlo o mlýn s kolem na horní vodu, byl tento vybaven též vantroky. Současně lze předpokládat, že každé vodní kolo vodního mlýna bylo chráněno před vodním živlem místem srážky s odtokovým žlabem (v prŕípadě potřeby je $\mathrm{v}$ tomto místě svedena voda mimo kolo a vypuštěna $\mathrm{z}$ náhonu). Místo srážky však bylo jednoznačně prokázáno pouze u vodního mlýna odkrytého u obce Dragacz (Górzyńska-Górzyński-Majewski 2011, 65).

Písemné prameny poskytují doklady o existenci výbavy a zařízení, které byly ve větší míře zaváděny nejspíše až od pozdního středověku a na vsi patrně až v průběhu raného novověku. Jde o lub (Elbel 2009, 9-27) a mechanické prosévání meliva (Štěpán-Křrivanová 2000, 17). Na základě zmínky v práci J. Hanušina lze současně předpokládat užívání více složení poháněných jedním kolem již na sklonku středověku (Hanušin 1970, 203).

\section{Závěr}

Středověký vodní mlýn doposud nebyl dostatečně probádán a z výše uvedeného je zřejmé, že do dnešních dnů provází výzkum těchto objektů značné interpretační nesnáze. Archeologie ve spolupráci s etnografií, ikonografií a historií nejsou doposud schopny odpovědět na otázku výkonu vodních kol a kapacity vodních mlýnů, jakož i rychlosti otáčení běhounu ve středověkém mlecím stroji. Dále není možné na základě současných znalostí vyjasnit průběh etablování kol na horní vodu ve středověku, není známa podoba čepu a způsob zajištění hřídele v ložisku. Současně je problematická absence mlecích kamenů na některých lokalitách, zvláště českých, 
s čímž kontrastují počty zlomků mlecích kamenů na bavorské lokalitě Dasing. V neposlední řadě je neuspokojivý nízký počet zjištěných artefaktů převodového mechanismu a kypřic a absence předpokládaných artefaktů, jako jsou násypný koš či lub aj. Neschopnost odpovědět na tyto otázky zrcadlí současný stav výzkumu, a tedy nedostatečnost pramenné základny. I přes veškeré tyto problémy a nezodpovězené otázky však byly shromážděny informace, na jejichž základě lze alespoň předpokládat podobu a vybavení stř̌edověkého venkovského vodního mlýna, která vyplývá z obrázků 8,15 a 16.

Vlastní stavba, dokud nebyla spojena s obytnou částí do známého trojdílného schématu, byla zřejmě pouze jakýmsi „obalem“ na mlýnský mechanismus bez tepelného komfortu, zhotovená na drážku či sroubená. Zaujímala plochu do $20 \mathrm{~m}^{2}$, výjimečně snad i větší. Jednoduchá střecha byla nejčastěji krytá šindelem či došky. Okna byla malá bez výplně a relativně velký vstupní otvor byl umístěn ve štítové či okapové stěně. Založení objektů lze očekávat u větších řek jak na pilotech s platformami, tak na pevném podloží s kamenným základem (obr. 15 a 16). Archeologické výzkumy prokázaly, že ve středověku lze předpokládat mlecí stroj vybavený vodním kolem na spodní či horní vodu ${ }^{2}$ nejčastěji o průměru do 4 metrů. Vodní kolo s palečním kolem byla zapuštěna do hřídele nejspíše na dlab, a ta byla začepována do ložisek, která stála na nějakém podkladu (kupříkladu dřevěných podpěrách). Dále byl mlýn vybaven palečním kolem s palci, které roztáčely cévník o průměru $25-30 \mathrm{~cm}$ s přibližně šesti cévy. Cévník pevně obepínal železí, které bylo zahrocené a neslo kypřici (pravděpodobně kovovou), na niž přesně nasedal mlecí kámen běhoun. Železí tak procházelo okem ležáku a bylo vystředěno kuželicí. Tyto mlecí kameny o průměru minimálně 60 a maximálně $80 \mathrm{~cm}$ vyráběné z křemenných drobně porézních pískovců či jiných vhodných hornin byly v našem prostředí opatřeny křesem. Mlecí složení nesla jednoduchá mlýnská hranice. Mlýnská díla byla vybavena náhonem vedoucím vodu z rybníka či jezového díla, který byl opatřen stavidlem (viz tab. 1). Výjimečně byla prokázána existence vantroků a místo srážky s odtokovým žlabem (v prŕípadě potřeby je v tomto místě svedena voda mimo kolo a vypuštěna $z$ náhonu).

Vzhledem ke stavu pramenné základny a mnohým interpretačním nejasnostem je zřejmé, že sestavení modelu českého středověkého venkovského vodního mlýna je problematické. Kupř́ikladu zevšeobecnění užívání marginálně zastoupených artefaktů v archeologických situacích se může v budoucnosti ukázat jako velmi omezené. Nalezené artefakty výstroje vodních mlýnů, stejně jako znalosti z jiných pramenů však nejsou v současné době schopny doložit více variant výstroje či typů pohonu vodního mlýna, než jaké zde byly prezentovány. Autorka si je toho vědoma a pokus o sestavení modelu chápe jako počátek systematického bádání o středověkých vodních mlýnech v České republice. Tento drobný příspěvek ke studiu vodních mlýnů může v budoucnosti sloužit jako podklad $\mathrm{k}$ diskusi ve světle nových objevů a idejí.

Tento příspěvek byl zpracován v rámci grantu SGS-2014-046 a významněji rozšiřuje již publikovaný text v elektronickém časopise Antropowebzin. Galusová, L. 2011: Archeologický výzkum vodních mlýnů: výsledky a perspektivy. In: Antropowebzin http://antropologie.zcu.cz/archeologicky-vyzkum-vodnich-mlynuvysledky-perspektivy, cit. 7. 12. 2014.

\section{Literatura}

ADLER, H.-HUNDSBICHLER, H., 1980: Eine spätmittelalterliche Wassermühle an der Thaya in Rabensburg, Fundberichte aus Österreich 19, 9-54.

BAGNIEWSKI, Z.-KUBÓW, P., 1977: Średniowieczny młyn wodny z Ptakowic na Dolnym Śleśsku Mittelalterliche Wassermühle aus Ptakowice in Niederschlesien, Kwartalnik Historii Kultury Materialnej 25, 3-30.

BEKOVÁ, M.-DRAGOUN, B., 2004: Slepotice - laténské a časně římské sídliště, etapa II a III. Jahodovmlýn zaniklý počátkem 15. století, Zprávy České archeologické společnosti - Supplément 56, 24-25.

2 Jiné typy kol nebyly doposud ve sledované oblasti prokázány. 
BENDER, W., 1974: Młyn z początku XIII wieku na południowym Mazowsku - Moulin du début du XIIIe Siècle en Mazovie du sud, Kwartalnik Historii Kultury Materialnej 22, 213-230.

BENEŠ, A.-BRAUN, P., 1984: Horusice, Vlkov, okr. Tábor, Výzkumy v Čechách 1980-81, 34, 134.

BERTHOLD, J., 2008: Eine hochmittelalterliche Wassermühle in Elfgen. Befunde, Funde, Rekonstruktion, Bonner Jahrbücher 208, 173-236.

- 2009: Die hochmittelalterliche Wassermühle von Elfgen, Mitteilungen der Deutschen Gesellschaft für Archäologie des Mittelalters und der Neuzeit 21, 199-204.

BREUNSDORF 2011: Breunsdorf - ein verschwundenes Dorf im westsächsischen Braunkohlenrevier. Archäologischer Befund und christliche Überlieferung (Smolnik, R., ed.). Dresden.

CZYSZ, W., 1998: Die ältesten Wassermühlen. Archäologische Entdeckungen im Paartal bei Dasing. Thierhaupten.

DRAGOUN, M., 2009: Jahodov. In: Deštník - Zpravodaj obce Deštné v O. h. [on-line]. Dostupné z: http:// www.obec-destne.cz/e_download.php?file=data/messages/obsah4_1.pdf\&original=destnik_2009_02. pdf [cit. 7. 12. 2014].

DURDÍK, T., 2001: Hrad Týřov. Vlastivědná knihovnička Společnosti přátel starožitností, svazek 4. Praha.

DVOŘÁKOVÁ, E.-MERTA, J., 2005: Vodní kolo - motor stř̌edověku. In: Město a voda. Praha, město u vody (Fejtová, O.-Ledvinka, V.-Pešek, J., edd.), 111-122. Praha.

ELBEL, P., 2009: Co to znamená, když „die mülen nicht in den sleiffen geen“. Aneb o jednom nesrozumitelném mandátu krále Zikmunda, znojemských mlýnech v pozdním středověku, omylech Zikmundovy kanceláře a úskalích ediční práce. In: Sborník Státního okresního archivu Znojmo 24 (Vrzáková, D. a kol., edd.), 9-27. Znojmo.

FRÖHLICH, J.-KOVÁŘ, D.-PEŠTA, J., 2011: Zaniklý obilný mlýn na Blehovském potoce u Osletína na Milevsku - Eine verschwundene Getreidemühle am Blehovský-Bach bei Osletín in der Nähe von Milevsko, AVJČ 24, 249-262.

GAITZSCH, W.-PÄFFGEN, B., 1995: Ein röhmische Metallhort bei Aldenhoven-Pattern/Kreis Düren. In: Ein Land macht Geschichte. Archäologie in Nordrhein-Westfalen Ausstellungskat. Schriften zur Bodendenkmalpflege in Nordrhein-Westfalen, Band 3 (Hellenkemper, H.-Horn, H. G.-Koschik, H. a kol., edd.), 256. Mainz - Köln.

GALUSOVÁ, L., 2011: Archeologie vodních mlýnů, výsledky a perspektivy - Archaeological research of water mills: outcomes, perspectives. Antropowebzin 2, 113-120 [on-line]. Dostupné z: http://antropologie.zcu.cz/media/document/galusova-2-2011.pdf [cit. 16. 4. 2015].

- 2014: Vodní díla ve vesnickém prostředí vrcholného a pozdního středověku v Čechách. Prostorové vazby a sídelní souvislosti - Waterworks in rustical environment of High and Late middle ages in Bohemia. Spatial Relationships and settlement context. Disertační práce, ulož. na Katedře archeologie FF ZČU.

GÓRZYŃSKA, A.-GÓRZYŃSKI, T.-MAJEWSKI, M., 2011: Późnośredniowieczny młyn z Mniszka na ziemi świeckiej ze stanowiska 16 - Late Middle Ages mill from Mniszek in Świecie county from site 16. In: Raport 2005-2006 (Kadrow, S., ed.), 59-68. Warszawa.

HANUŠIN, J., 1970: Pojem a klasifikácia mlynov na Slovensku (Príspevok ku studiu starých mlynov a mlynárstva) - Begriff und Klasifikation der Wassermühlen in der Slowakei (Beitrag zum Studium unserer alten Mühlen und der Müllerei), Slovenský národopis 18/2, 177-222.

HEJHAL, P.-HRUBÝ, P.-MALÝ, K., 2006: Doklady rudních mlýnů ze středověké důlní aglomerace Staré Hory u Jihlavy, AVJČ 19, 259-288.

HERZIG, F., 1998: Zum Stand der dendrochronologischen und holzanatomischen Untersuchungen an den frühmittelalterlichen Bauhölzern aus Grending-Großhöbing. In: Beiträge zur Archäologie in Mittelfranken 4 (Nadler, M.-Pfauth, U., edd.), 247-256. Büchenbach.

HERZIG, F.-LIEBERT, T.-NADLER, M., 1998: Die Müller Karls des Großen - Frühmittelalterliche Wassermühlen im Schwarzachtal bei Großhöbing. Stad Grending, Landkreis Roth, Mittelfranken. In: Das archäologische Jahr in Bayern 1997 (Ebner, D., ed.), 143-146. Stuttgart.

HOCH, A., 2008: Doklady středověkých rudních mlýnů a zařízení na drcení rudy na Jihlavsku a Havlíčkobrodsku. Bakalářská diplomová práce, ulož. v ÚAM FF MU.

HÖCKMANN, O., 1994: Eine Schiffsmühlen aus den Jahren um 760 n. Chr. in Gimbsheim. Kreis Alzey-Worms, Mainzer Archäologische Zeitschrift 1, 191-209.

ISSLEIB, H., 1953: Die betriebsanlagen der alten Wassermühle am Ahrensfelder Teich, Hammaburg 4, Heft $9,68-70$.

JACCOTTEY, L.-FARGET, V., 2011: Les normes de dessin des meules rotatives. In: Évolution typologique et technique des meules du Nèolithique à l'an mille. Actes des IIIe Rencontrres Archéologiques de l'Archéosite gaulois. Aquitania Supplément 23 (Buchsenschutz, O.-Jaccottey, L.-Jodry, F. a kol., edd.), 51-68. Bordeaux. 
JÜTTEMANN, H., 1990: Bauernmühlen im Schwarzwald. Dokumentation und Restaurierung bäuerlicher Alltagstechnik. Stuttgart.

KAŠPAR, V.-SMEJTEK, L.-VAŘEKA, P., 1999: Zaniklý sídlištní komplex Ústupenice na Sedlčansku (okr. Př́ibram). Archeologický výzkum mlýna z pozdního středověku (předběžná zpráva) - Verwüsteter Siedlungskomplex Ústupenice auf dem Sedlčansko-Gebiet (Bez. Př́ibram), AH 24, 101-109.

KELLERMANN, V., 1953: Die Ausgrabung der mittelalterlichen Wassermühlen von Ahrensfelde, Hammaburg 4, Heft 9, 64-67.

KIND, T., 2007: Das karolingerzeitliche Kloster Fulda - ein „monasterium in solitudine“. Seine Strukturen und Handwerksproduktion nach den seit 1898 gewonnenen archäologischen Daten. In: Millennium Studien. Studien zu Kultur und Geschichte des ersten Jahrtausends n. Chr. - Millennium Studies. Studies in the culture and history of the first millennium C. E. 5/1 (Hening, J., ed.), 367-409. Berlin - New York.

KLÁPŠTĚ, J., 1978: Středověké osídlení Černokostelecka - Die Mittelalterliche Besiedlung im Raum von Kostelec nad Černými lesy, PA LXIX, 423-475.

KOŠŤÁL, J., 2012: Říční mlýn ve Velkém Pořící. In: Newsletter 2. Elektronický newsletter společnosti Labrys, o.p.s. (Blažková, T., ed.), 2. Praha.

KRÜGER, F., 1934: Eine frühmittelalterliche Wassermühle in Bardowick, Mannus. Zeitschrift für Deutsche Vorgeschichte 26, 344-354.

KUDRNÁČ, J., 1971: Zlato v Pootaví. Písek.

- 1972: Objevy středověkých zlatorudných mlýnů v Čechách - Die Entdeckung mittelalterlicher Goldmühlen in Böhmen, AR XXIV, 428-432.

- 1983: Přehled archeologického zkoumání památek po těžbě zlata v jižních Čechách 1972-1982 - Übersicht über die archäologische Forschung der Denkmäler der Goldgewinnung in Südböhmen in den Jahren 1972-1982, AVJČ 1, 7-26.

KUDRNÁČ, J.-HUML, V., 1969: Výzkum středověkých technických zařízení v Písku - Die Erforschung mittelalterlicher technischer Einrichtungen in Písek, AR XXI, 37-42.

MAGER, J.-MEIßNER, G.-ORF, W., 1988: Die Kulturgeschichte der Mühlen. Leipzig.

MANNING, C., 2007: Harnessing the tides: the early medieval tide mills at Nendrum Monastery, Strangford Lough by Thomas McErlean, Norman Crothers, Belfast 2007, Pp 468. In: The Journal of the Royal Society of Antiquaries of Ireland 137, 165-167.

MAŘÍKOVÁ, M., 2005: Stř̌edověké mlýny v českých zemích - Mittelalterliche Mühlen in den böhmischen Ländern. In: Mediaevalia Historica Bohemica 10, 89-148. Praha.

MILLE, P., 2011: Les moulins hydrauliques mis au jour sur le territoire français, Evolution technique, VIIIe-XIVe siècles [on-line]. Dostupné z: http://www.canal-u.tv/video/musee_archeologique_du_jura/ les_moulins_hydrauliques_mis_au_jour_sur_le_territoire_francais_evolution_technique_viiie_xive_ siecles_pierre_mille_inrap.8886 [cit. 27. 3.2015$]$.

MLYNKA, L., 2006: Vodný mlyn a jeho terminológia v slovenčine a v slovanských jazykoch - Water Mills and their Terminology in Slovak and Slavic Languages, Studia Academica Slovaca 35, 409-421.

NEKUDA, R., 2006: Archaeological survey of the medieval watermill in Mstěnice 1998-2005 - Archeologický výzkum středověkého vodního mlýna ve Mstěnicích 1998-2005. In: Ve službách archeologie VII (Hašek, V.-Nekuda, R.-Ruttkay, M., edd.), 128-141. Brno.

NEYSES, A., 1983: Die Getreide mühlen beim römischen Land und Weingut von Lösnich, Trierer Zeitschrift für Geschichte und Kunst des Trieres Landes und seiner Nachbargebiete 46, 209-221.

NOVÁČEK, K.-VAŘEKA, P., 1993: Libkovice - vývoj a zánik severočeské vesnice, Dějiny a současnost 15/1, 49-51.

- 1994: Libkovice, okr. Most - záchranný archeologický výzkum (předběžná zpráva). Mediaevalia archaeologica Bohemica 1993. PA - Supplementum 2 (Fridrich, J.-Klápště, J.-Vařeka, P., edd.), 223. Praha.

PETRÁŇ, J., 1985: Dějiny hmotné kultury 1. Praha.

PFAUL, P., 1967: Der Bellifortis von Conrad Kyeser aus Eichstätt, 1405. Erster Band. Düsseldorf.

RICHTEROVÁ, J., 1987: Příspěvek archeologického průzkumu k počátkům tzv. slánského domu - Der Beitrag archäologischer Forschunger zu den Anfängen des nach der böhmischen Stadt Slaný genanten Haustyps, AH 12, 183-188.

ROLLIER, G., 2011: Les traces d'installation de meunerie du Xe siècle. Le moulin des XIe-fin XIIe siècle. In: Archéologie en Franche-Comté. Fouilles Archèologiques de la LGV Rhin-Rhône. Archéologie en Franche-Comté 3 (Rollier, G., ed.), 50-53. Jura.

SCHMIDT, G.-UNTERKIRCHER, F., 1967: Krumauer Bildercodex. Österreichische Nationalbibliothek Codex 370. Edice Codices selecti. Vol. 13. Graz, 128v. 
SCHWARZLÄNDER, S., 2003: Sraße durch die Zeit. Neubau der Ortsumgehung Jüterbog, Landkreis Telfow-Fläming. In: Archäologie in Berlin und Brandenburg 2002 (Gringmuth-Dallmer, E. a kol., edd.), 143-145. Stuttgart.

SMETÁNKA, Z.-KLÁPŠTĚ, J., 1981: Geodeticko-topografický průzkum zaniklých středověkých vsí na Černokostelecku - Geodetical-topographical survey of deserted medieval villages in the Kostelec nad Černými Lesy region, PA LXXII, 416-458.

SUPPAN, R., 1995: Mühlen, Bäche, Wasserräder. Geschichte und Funktion der wasserbetriebenen Mühlen. Graz.

ŠTĚPÁN, L., 2000: K otázce zavádění vodních kol ve stř̌edověké hutní výrobě. In: Z dějin hutnictví 29 (Rasl, Z.-Zamrzlová, J., edd.), 55. Praha.

- 2012: První středověké mlýny poháněné koly na vrchní vodu a jejich mlecí kameny. In: Sborník referátů ze semináře Vodní mlýny IV (Šimek, R., ed.), 14-19. Vysoké Mýto.

ŠTĚPÁN, L.-KŘIVANOVÁ, M., 2000: Život a dílo mlynářů a sekerníků v Čechách I. Praha.

ŠTĚPÁN, L.-URBÁNEK, R.-KLIMEŠOVÁ, H., 2008: Dílo mlynářů a sekerníků v Čechách II. Praha.

TUTLIES, P., 2006: Eine karolingische Wassermühle im Rotbachtal. In: Archäologie im Rheinland 2005 (Kunow, J., ed.), 106-108. Stuttgart.

VÖLKER, E., 2004: Die Gielsdorfer Mühle im Gamengrund, Archäologie in Berlin und Brandenburg 2003, $149-151$.

WESTPHALEN, T., 1997: Die Thomasmühle, Archäologie aktuell im Freistaat Sachsen 1996, $215-217$.

ZRŮSTOVÁ, V., 2007: Zaniklá středověká vesnice Šonava na Poličsku - The Extinct medieval village Šonava in Poličsko. Bakalářská práce, ulož. na Katedře archeologie FF ZČU.

ŽEMLIČKA, J., 2012: Česká krajina ve středověké transformaci - The Czech Landscape in Medieval Transformation, Mediaevalia Historica Bohemica 15, 7-43.

\section{Prameny}

Bayerische Staatsbibliothek München, Deutsches Manuskript, Sign. Clm 197.

Bayerische Staatsbibliothek München, Der Hussitenkrieg, um 1430, Cod. lat. 197/I, Fol. 23r.

Bayerische Staatsbibliothek München, Der Hussitenkrieg, um 1430, Cod. lat. 197/I, Fol. 18v.

\section{Zusammenfassung}

\section{Die Wassermühle als archäologisches Grabungsobjekt}

Der vorliegende Beitrag fasst die bisher veröffentlichten archäologischen Grabungen zusammen, die als mittelalterliche Wassermühlen oder als Mühlen interpretiert werden, deren Kontinuität bis ins Mittelalter reicht und rekonstruiert auf deren Grundlage hypothetisch Aussehen und Ausstattung einer Wassermühle wie sie in den ländlichen Gebieten Tschechiens betrieben werden konnte. Analog zu den tschechischen Gebieten wurden Beispiele aus Deutschland, Österreich und Polen herangezogen.

Im Hinblick auf den Stand der Quellenlage und viele Interpretationsunklarheiten war die Erstellung eines Modells einer ländlichen Wassermühle problematisch. Auch trotz dieser Schwierigkeiten ist es gelungen, interessante Erkenntnisse über Wassermühlen zusammenzutragen, die in Böhmen und Mähren aus archäologischer Sicht bislang nur wenig untersucht wurden.

Der vorliegende Beitrag wurde im Rahmen des Studentenförderwettbewerbs SGS-2014-046 ausgearbeitet und ist eine beträchtlich erweiterte Fassung des in der elektronischen Zeitschrift Antropowebzin bereits veröffentlichten Textes Galusová, L., 2011: Die archäologische Grabung an Wassermühlen: Ergebnisse und Perspektiven. In: Antropowebzin http://antropologie.zcu.cz/archeologicky-vyzkum-vodnich-mlynu-vysledky-perspektivy, abgerufen am 7. Dezember 2014.

Mgr. Lucie Galusová, Katedra archeologie Filozofické fakulty Západočeské univerzity v Plzni, Sedláčkova 15, 30614 Plzeň, kaluc@centrum.cz 
